\title{
PANOFSKY ÖLÇEĞİNDE KARŞILAŞTIRMALI ADEM VE HAVVA IKONOGRAFISI*
}

\author{
Adam and Eve Comperative Iconography on the Panofsky Scale
}

Nur Sena DEMiR ${ }^{1}$

\begin{abstract}
ÖZET
Sanat Tarihi alanında Adem ile Havva'nın kutsal kitaplarda yer alan hikayelerini anlatan resimler önemli yer tutmuştur. $\mathrm{Bu}$ eserlerin birçok sanatçı tarafından farklı teknik (minyatür, yağlıboya, fresk, mozaik vb.) ve kompozisyonlarda yapıldığ bilinmektedir. Adem ve Havva'nın yaratılışı ile başlayarak, yasak meyvenin yenmesi ve ardından cennetten kovulmaları şeklinde anlatılan ikonografi sanatçıların bireyselliği ile eserlerinde uygulanmıștır. İslam coğrafyasında minyatürlerde, Hristiyan coğrafyasında ise Batı tarzı resimlerde Adem ile Havva'nın çok sayıda betimini görmek mümkündür. Bu tasvirlerin ikonografileri üzerinden birbirleri ile karşılaştırmaları ve analizleri, Alman Sanat Tarihçi Erwin Panofsky'nin ortaya koyduğu görsel sanatlarda anlam teorisi olarak niteleyebileceğimiz İkonografik ve İkonolojik Eleştiri Yöntemi'ne uygun olarak değerlendirilmiştir. Eserlerin geleneklerine bağlılı̆̆ı, sanatçıların bireyselliği, Adem ile Havva betimlemelerinin gelişmişliği ve birbirleri ile benzerlik ve farkl1lıkları üzerinde durulmuştur. Adem ve Havva ikonografisi; Adem'in Yaratılışı ve Meleklerin Adem'e Secdesi, Havva'nın Yaratılışı, Yasak Meyve ve Cennetten Kovulma başlıkları altında resimlerle incelenmiştir. Çalışmaya konu olan minyatürler ve Batı tarzı resimler ait oldukları toplumların öğretileri de dikkate alınarak birbirleri ile karşılaştırılmıştır. Adem ve Havva'nın yaşam hikayesi üzerine dünyada sayısız resim bulunmakla beraber, bu çalışmaya hepsini dahil etme imkanı olmaması sebebiyle spesifik eserler seçilmiştir. Çalışmada; Kur'an-1 Kerim kaynaklığında İslam sanatçıları tarafından oluşturulan Falname, Kısassü'l-Enbiya, Hadikatü's-Süeda, Menafi El-Hayvan, Kitab'el-Asar el Bakiya ve Zübdetü't Tevarih gibi eserlerde yer alan minyatürler ile Bat1 sanatında Michelangelo Buonarroti, Hugo Van der Goes, Hieronymus Bosh, Albrecht Dürer, Jan Bruegel, Paolo Uccello, Massaccio, Charles-Joseph Natoire ve Tiziano Vecellio gibi ünlü sanatçıların Tevrat ikonografisi üzerinden yapmış oldukları resimlere yer verilmiştir. İslam sanatında minyatürlerde iki boyutlu uygulamalar ile perspektif anlayışının olmayışının yanı sıra Batı sanatındaki üç boyutlu resmetme geleneği, derin perspektif uygulamaları, canlı renkler ve gerçekçilik Erwin Panofsky'nin anlam teorisini karşılamaları açısından oldukça önemlidir. Tüm bu eserlerde özellikle Şeytan ve yılan tasvirlerindeki çeşitlilik, Adem ile Havva'nın yasak meyve sahnesinden önceki ve sonraki durumlarını ifade eden sembolik uygulamalar ve yasak meyvenin resimlerde elma olarak nitelenmesi durumu dikkat çekici noktalar olmuştur.
\end{abstract}

Anahtar Kelimeler: İkonografi, Panofsky, Adem, Havva, Yasak Meyve.

\begin{abstract}
Paintings, visualizing Adam and Eve's anecdote in holy books, have taken an impacting position in the field of art history. This has been known, that these art pieces have been done by many artists in different forms (miniature, oil painting, fresco, mosaic etc.) and compositions. Iconographies, explaining Adam and Eve's life story which starts by being created then eating the forbidden fruit and being banned from heaven, have been applied by individuality of the artists over art pieces. We can see many images of Adam and Eve in miniature of Islamic geography and western style drawings of Chritian geography. Iconographical based comparisons and analysis done over art pieces have been evaluated based on the theory of German Art Historian, Erwin Panofsky, called meaning in visual arts theory which is an "Iconographic and Iconologic Critisism Approach". This study has been done over dependency of the art on its traditions, individuality of the artist and evolution of Adam and Eve images and the similarities and differences between them. Adam and Eve's Iconography, categorised into The Creation of Adam and Prostration of Angels to Adam, The Creation of Eve, Forbidden Fruit and Being Cast Out from Eden topics, has been studied using pictures. Although there are numerous pictures in world about the story of Adam and Eve, specific works have been chosen, because there is no possibility to include them all in this study. Along with important miniatures found in pieces like Falname, Kısassü'l-Enbiya, Hadikatü's-Süeda, Menafi El-Hayvan, Kitab'el-Asar el Bakiya and Zübdetü't Tevarih, drawings made by many other artists includings Michelangelo Buonarroti, Hugo Van der Goes, Hieronymus Bosh, Albrecht Dürer, Jan Bruegel, Paolo Uccello, Massaccio, Charles-Joseph Natoire and Tiziano Vecellio have been used in this study. In addition to the lack of perspective understanding and two-dimensional applications in miniatures, the tradition of three-dimensional painting in Western art, deep perspective applications, vivid colors and realism are very important in meeting Erwin Panofsky's theory of meaning. In particular, the diversity of the depictions of the devil and the snake, the symbolic practices describing Adam and Eve's states, before and after forbidden fruit scene, and the status of the forbidden fruit being an apple is very eye catching.
\end{abstract}

Keywords: Iconography, Panofsky, Adam, Eve, Forbidden Fruit. 


\section{EXTENDED ABSTRACT}

Iconography is the source information, which we apply to explain the situations and events, that we cannot interpret with our daily life information. Iconographies of the works in visual arts, including many paintings, miniatures, sculptures, etc., which are the subject of Art History, guide us in understanding and interpreting them. The theory of meaning, also known as the Iconological and Iconographic Criticism Method introduced by the German art historian, Erwin Panofsky, as an achievement of the search for meaning in the visual arts, offers us the opportunity to examine the works in various dimensions with their iconography. Each society has its own unique understanding of art and works of art with traces of its artists' own culture. These works have been sometimes used in religious subjects, and sometimes in non-religious subjects like landscapes, objects, figures, etc. Indeed, in the beginning, the tradition of painting religious subjects, as in the art itself, was shaped to the extent, allowed by beliefs in societies. In Islamic societies, various works have been made in tradition of miniature painting by some Islamic artists in response to prohibition of depiction, whose existence is known especially on religious issues. In Christian geography, painting in Western art, that is constantly evolving and changing, has become a tool to explain their religion to the public by painting religious subjects, and to make religion easier to learn and adopt. The artists, who were initially given the opportunity to paint only religious subjects under the oppression of church, began to paint non-religious subjects with the new art movements, that emerged with the change of the age and the effectiveness of free thinking. As a result, religion has become a tool for artists, not a purpose in their works. In this sense, the works put forward on religious issues, in Western art, developed day by day and started to decorate church walls and ceilings. Representing the origin of the human race, which was accepted by three scriptures and religions, Adam and Eve have been the subject of many works created both in Islamic geography and in the Christian geography. The stories of Adam and Eve, beginning with the creation process and resulting in the being casted out of heaven by eating the forbidden fruit, are written in holy books. The information given in holy books gives us the opportunity to learn the iconography of the works. In the study, the similarities and differences between works on Adam and Eve subject belonging to different religions, which are put forward in societies, will be explored by the loyalty of the artists to the holy books and the comparisons of the two different religions and the two holy books. The existence process of the works will be evaluated based on iconography, and necessary classification will be done. The purpose of this study is to find how much the works bear the traces of the period, in which they and their contribution to the development process of Art History were made, with their iconographic accuracy. The works of Güner Inal, Metin And, Uşun Tukel, Serap Yüzgüller, Bedrettin Cömert et al., art historians who are specialized in their fields, that differ in terms of content, are important publications. The main sources, which we have referred to, are Quran and the Torah from publications and holy books of Erwin Panofsky. In line with the purpose determined at the beginning of the study, library and archive studies were conducted and various publications and accessible pictures were scanned, and necessary information was collected on the subject. The life story of Adam and Eve, which formed the basis of this study after the introduction, has been described chronologically under the titles of Adam's Creation and Angel's Prostration to Adam, Eve's Creation, the Eating of the Forbidden Fruit and the cast out of Heaven. The miniatures and Western-style paintings, that are the subjects of the study, were compared with each other by taking teachings of the communities they belong to into consideration, with the necessary classification study. Although there are numerous pictures in world about the story of Adam and Eve, specific works have been chosen, because there is no possibility to include them all in this study. While benefiting from the works titled Kısassü'l-Enbiya, Külliyat-1 Tarih, Hadikatü's-Süeda, Falname, Kitab'el-Asar el Bakiya, Menafi El-Animal, and Zübdetü't-Tevarih for Islamic miniatures, in Western art, Hugo Van der Goes, The works of Hieronymus Bosch, Michelangelo, Tiziano Vecellio, Albrecht Dürer, Jan Gossart, Jan Bruegel, Uccello, Massaccio and Charles-Joseph Natoire are included. In the conclusion part, the study has been evaluated once again within the general lines, and concluded by its important parts being emphasized. Finally, publications, that give reference to the research, are given. 


\section{GíRiş}

Gündelik hayattaki bilgilerimizle yorumlayamadığımız durum ve olayları açıklayabilmek amacıyla başvurulan yazılı veya sözlü kaynaklar ikonografi olarak isimlendirilmektedir (Tükel ve Yüzgüller, 2018). İkonografi bir kaynak bilgisidir. Bu kaynak bilgisine hayatın her alanında ve herhangi bir konuda ihtiyaç duymak mümkündür.

Eserlerin anlaşılması üzerine birbirine benzer çeşitli yaklaşımlar olabileceği gibi sanat tarihçiler tarafından kabul görmüş bir teori mevcuttur. Bu teori ünlü Alman sanat tarihçi Erwin Panofsky tarafından öne sürülmüş olan İkonografik ve İkonolojik Eleştiri Yöntemi olarak bilinen bir anlam teorisi'dir (Panofsky, 1955: 12-13). Panofsky, sanat yapıtını biçim, konu ve içerik açısından ele alan ve günümüz sanat tarihi yönteminin de temelini oluşturan üç aşamalı inceleme düzeyini tasarlamıştır (Dağlığlu ve İnce, 2018: 947). Panofsky bir resmin algilanabilmesi, dolayısıyla estetik bakımdan yorumlanabilmesi için, üç ayrı evrede gerçekleşen anlamların saptanması gerektiğini söylemektedir (Cömert, 2008: 15). Bir eserde aranacak anlamları sınıflandırma yoluna giden Panofsky'e göre eserler: doğal anlam, ikonografik anlam ve asıl anlam-içerik olarak üç aşamada incelenmelidir. Kendi içinde ikiye ayrılan doğal anlam, olgusal ve ifadesel anlamı, ifadesel anlam ise figür ve ortam bazında iki ayrı başlığı bünyesinde barındırmaktadır. Olgusal anlam, esere baktığımızda hiçbir anlam yüklemeksizin gördüğümüzü betimleme durumudur. İfadesel anlamın figür ve ortam bazında değerlendirilmesi ise eserde yer alan figürlerin gerek duruş pozisyonları gerek yüz ifadeleri gerekse içlerinde bulundukları ortamın 1şık-renk oyunları ve çeşitli unsurlarla yansıttığı anlamdır. İkinci aşamada yer alan ikonografik anlam eserin kaynak bilgisidir. Esere kaynaklık eden yayınlar, efsaneler, hikayeler, tarihi olaylar ve daha pek çok materyal ikonografinin temelini oluşturmaktadır. Asıl anlam-içerik ise eserin ortaya koyulduğu dönemin ve bulunduğu ortamın şartlarını ne derece yansitıyor olduğudur. Sanat eserleri Panofsky tarafından ortaya atılan bu anlam teorisi ile pek çok yönden daha rahat incelenme imkanı bulmuştur. İşte bu çalışmada farklı dinlere mensup sanatçıların, ilk insan Adem ve eşi Havva ile ilgili yaptıkları resimler, Panofsky'nin anlam teorisi dikkate alınarak karşılaştırılacak ve ikonografilerini ne derece yansıttıkları ortaya konulmaya çalışılacaktır.

Kutsal kitaplarda Adem ile Havva'nın hikayesi; yaratılış, yasak meyvenin yenmesi ve akabinde cenetten kovulmaları şeklinde anlatılmaktadır. Bu anlamda İslam coğrafyasındaki tasvir yasağına karşılık Kur'an-1 Kerim kaynaklığında minyatür eserlerde yer verilen sahneler ile Batı dünyasında Tevrat'a bağlı olarak resmedilen sahneler mukayese edilecektir. Ortaya koyuldukları dönemlerde çağdaşlarına kıyasla özgün uygulamalarla öne çıkan Adem ve Havva tasvirlerinin ikonografileriyle ne derece örtüştükleri, bu ikonografiyi hangi ölçüde yansıttıkları detaylı olarak incelenecektir. $\mathrm{Bu}$ kapsamda yayınlarda ve müze kataloglarında yer alan sayısız resim ve minyatür arasından oldukça farklı örnekler seçilerek incelemeye dahil edilmiştir.

\section{Adem'in Yaratılıșı ve Meleklerin Adem'e Secdesi}

Adem'in yaratılışına dair Kur'an-1 Kerim'de pek çok surede, çeşitli ayetlerde anlatımlar mevcuttur. Kur'an-1 Kerim'de yimi beş yerde benzer şekillerde Adem'in Yaratılış sürecine değinilmiştir. 
En ayrıntılı anlatım A'raf, Mü’minun ve Secde surelerindeki ayetlerde geçmektedir. Mü'minun suresinin 12.ayetinde, "Andolsun biz insanı çamurdan (süzülüp çıkartılmış) bir özden yarattık." şeklinde ifade edilen Yaratılış pek çok yerde aynı şekilde anlatılmıştır. Yine bir diğer örnek olarak Secde suresinin 9.ayetinde, “...Sonra onu tamamlayıp şekillendirmiş ve ona kendi ruhundan üflemiştir." şeklinde ifade edilmiştir. Araf suresinin 27.ayetinde ise, "Sizi yarattık, sonra size şekil verdik, sonra da meleklere Adem'e secde edin dedik. Hepsi secde ettiler yalnız iblis etmedi. O secde edenlerden olmadı.." şeklinde anlatılmıştır. Kur'an-1 Kerim'de açık bir şekilde yer alan bu ifadelere karşılık, Tevrat'ta ise "Ve RAB dedi; Suretimizde, benzeyişimize göre insan yapalım; ve denizin balıklarına, ve göklerin kuşlarına ve sığırlara, ve bütün yeryüzüne, ve yerde sürünen her şeye hâkim olsun. Ve RAB insanı kendi suretinde yarattı; onları erkek ve dişi olarak yarattı"(Tekvin 1:26-27) şeklinde Yaratılış olayına yer verilmiştir. Devamında meleklerin secdesine değinilmiş tıpkı Kur'an-1 Kerim'deki gibi Şeytanın secde etmeyişi anlatılmıştır. Kutsal kitaplar bu konuda birbirleri ile örtüşür nitelikte bilgiler vermektedir.

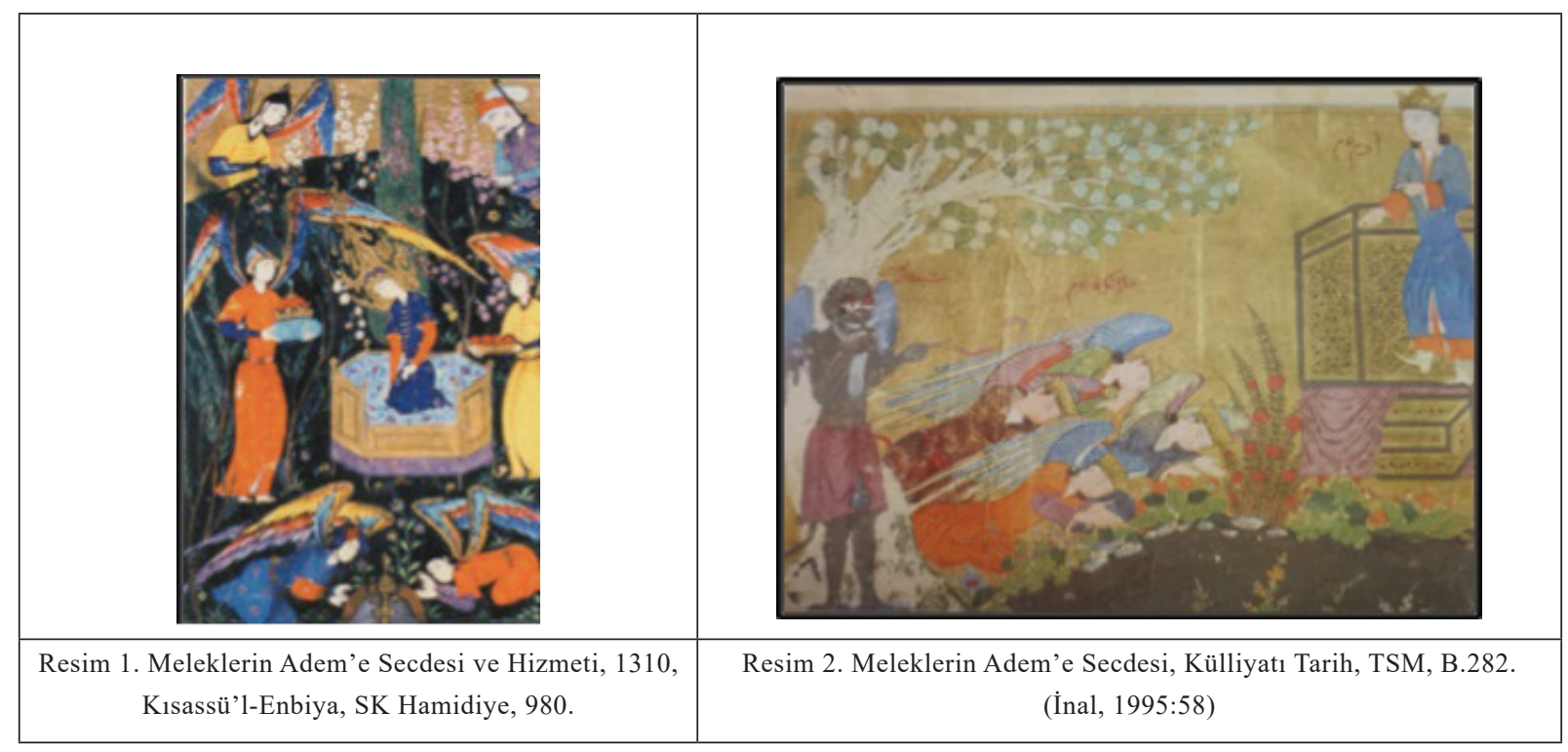

İslam dünyasına ait minyatürler, Kuran-1 Kerim'deki ikonografi bilgisiyle oldukça uyumludur (Resim 1-2). Farklı sanatçıların elinden çıkmış olan minyatürlerde melekler emrolundukları üzere Adem'e secde ederken, Şeytan ise öfkeli veya küskün bir ifade ile bir kenarda dururken resmedilmiştir. Minyatürlerde genellikle Adem'in baş çevresi ya da bütün bedeni, kutsallığını ifade eden bir hare ile çevrilmiştir. Külliyat-1 Tarih adlı eserde geçen bir minyatürde ise Adem kutsallı̆̆ının ifadesi olarak dörtgen planlı altın bir taht üzerinde ayakta resmedilmiştir (Bayrak Kaya, 2020: 211) (Resim 2). Resimde iki boyutlu uygulamanın hissedildiği minyatürlerde verilen detaylar, figürlerin yüz ifadeleri, duruş pozisyonları gibi uygulamalar minyatür resminin gelişmişlik düzeyini ortaya koymaktadır. 


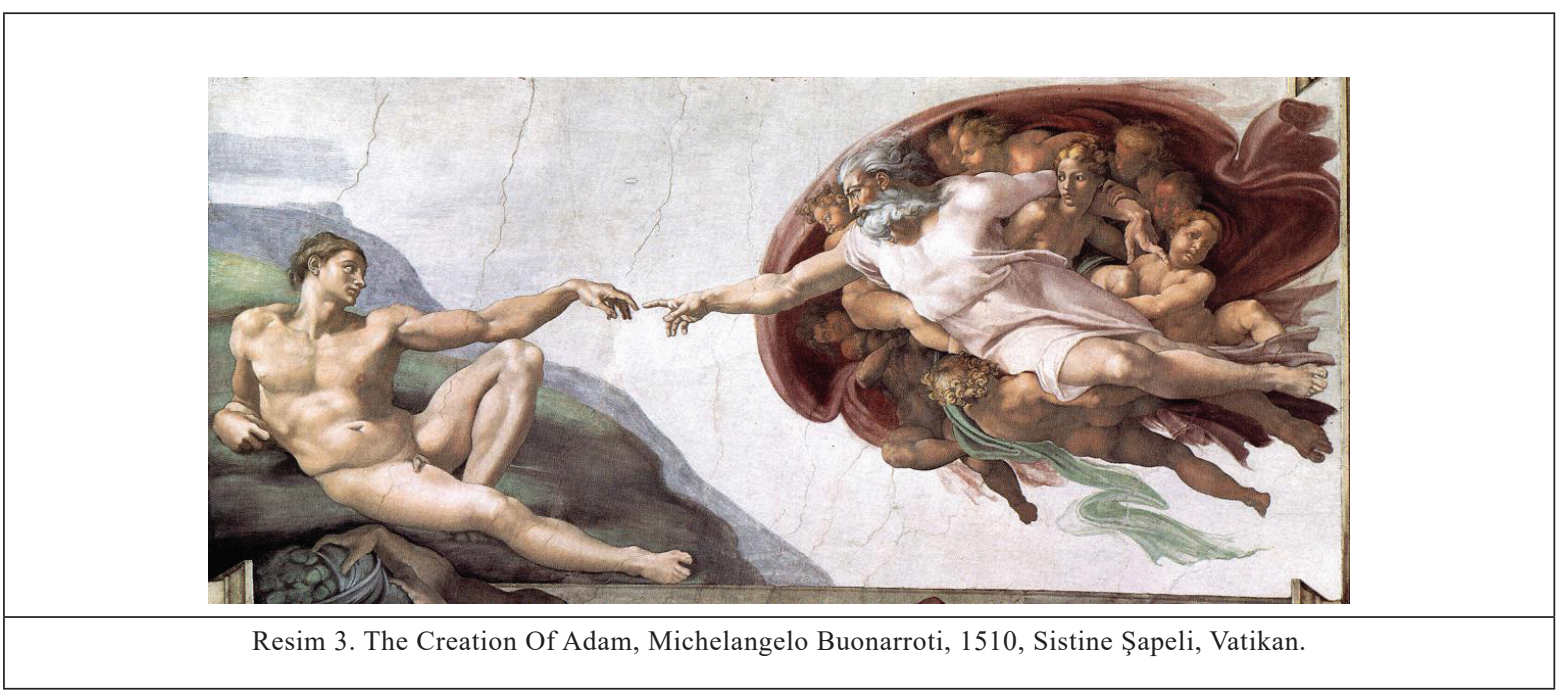

Sanatçı Michelangelo tarafından yapılmış Adem'in Yaratılışı konulu duvar freski (Resim 3) minyatürlere kıyasla çağdaş zamanın Batı sanatında görülen üstün bir başarı örneğidir. Vatikan' daki Sistine Şapeli'ni boydan boya Mukaddes Kitap'la süsleyen sanatçı bu sahnede Adem'in yaratılışı konusunu resmetmiştir (Altuna, 2019: 50). Michelangelo, dört sene boyunca Papa'nın baskısının altında kendini insanüstü bir çabayla verdiği çalışmasının bir parçası olan Adem'in Yaratılışı'nda Yaratıcı'nın Adem'e ruhundan üflemesi ikonografisini bireyselliği ile yorumlamıştır. "Ve Rab yerin toprağından Adem'i yaptı, ve onun burnuna hayat nefesini üfledi; ve Adem yaşayan can oldu." (Tekvin 2:7) ifadesine uygun olarak Tanrı ile Adem arasında bir bağlantı sağlamış, dini ikonografiyi bireyselliği ile harmanlayarak başarılı bir şekilde resmetmiştir. Sahnede Yaratıcının eliyle dokunduğu Adem'e yaşam verişi gösterilmiştir (Tükel vd., 2018: 20). Çoğu yorumcuya göre ise Tanrı Adem'i tam anlamıyla "yaratmak" üzeredir; parmakları birbirine değmektedir (Minor, 2013: 87). Freskte sağ tarafta tasvir edilen Tanrı figürü için yaratıcının mutlak akıl ve sevginin temsili olduğunu gösterir şekilde resmedildiği yorumu yapılabilir. Yaratıcı etrafındaki meleklerle, yerde uzanan Adem'e dokunmak üzeredir; bu sırada Adem cansız ve güçsüz bir görünüm içerisindedir. Tanrı figüründeki dinamizm ile henüz kıpırdayamayacak kadar hareketsiz görünen Adem figüründeki dinginlik, yapıta dramatik bir hava katmıştır (Tükel vd., 2018: 20). Duruşlar ve anatomik idealizm ile dikkat çeken bu uygulama sanatçının bireyselliğini ortaya koyarken aynı zamanda örneklerini gördüğümüz minyatür resimlerin çok ötesinde bir gelişmişliği de yansıtmaktadır. Bunların dışında figürlerin vücut proporsiyonları, yüz ifadeleri, renklerin uygulanışı ve canlılıkları İslam minyatürü ile Batı resmindeki uygulamaların farklılıklarını bizlere gösteren diğer özelliklerdir.

\section{Havva'nın Yaratılışı}

Kur'an-1 Kerim'de Havva'nın yaratılışını anlatan özel bir bölüm bulunmamaktadır. Ancak bazı surelerde Havva'nın yaratılışına dair ipuçları veren ayetler mevcuttur. A'raf, En'am ve Nisa surelerinde çeşitli ayetlerde Havva'nın, Adem'in kendisinden yaratıldığını dolaylı yoldan anlatan ifadeler vardır. Bu durum A'raf suresinin 7. Ayetinde, "Sizi tek bir nefisten yaratan ve gönlünün huzura kavuşacağ 
eşini de ondan var eden Allah 'tır." şeklinde ifade edilirken, Nisa suresinin 4.ayetinde, "Ey insanlar! Sizi tek nefisten yaratan, ondan eşini var eden ve her ikisinden pek çok erkek ve kadını türeten Rabbinize karşı gelmekten sakının." şeklinde anlatılmaktadır. Açık bir şekilde Havva'nın varoluş sürecine değinilmemiş olsa da Kur'an-1 Kerim'de Havva'nın Adem'den yaratılmış olduğu anlatılmak istenmiştir.

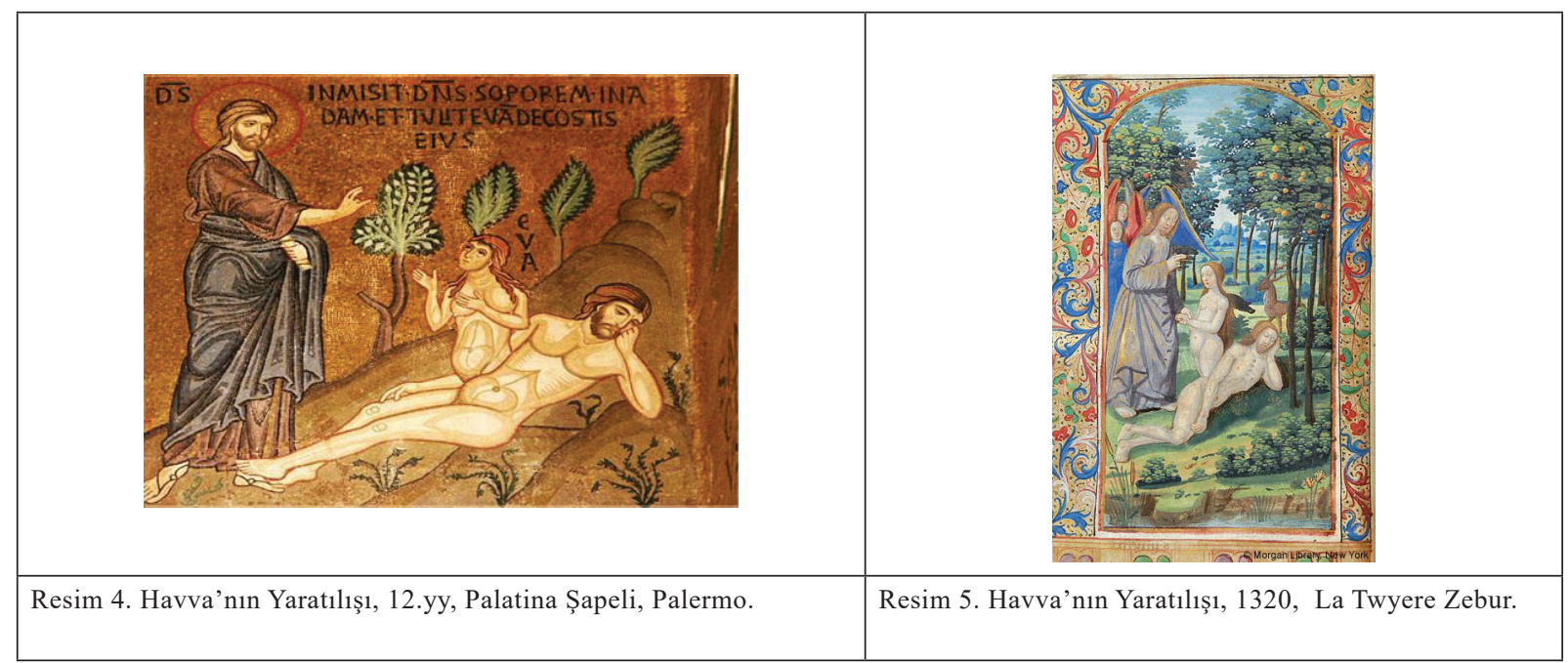

Eski Ahit adiyla da bilinen Tevrat'ta ise, "RAB Tanrı, Adem'e derin bir uyku verdi. Adem uyurken RAB Tanrı onun kaburga kemiklerinden birini çıkardı yerini etle kapadı. Adem'den aldığı kaburga kemiğinden bir kadın yaratarak onu Adem'e getirdi." (Tekvin 2:21-22) ifadeleriyle açık bir şekilde Havva'nın yaratılışı anlatılmıştır. Havva'nın yaratılışını konu edinen resimleri gördüğümüzde bunların Batı tarzında yapıldığını anlamak güç değildir. Çoğunlukla fresko olarak yapılan bu tasvirler dönemlerinin sanat anlayışlarını yansıtır niteliktedir. Eserlerde Yaratıcı, bir insan tasviri ile verilmiş, üzerinde pelerini ve başında halesi ile bir eli karşıya uzanmış şekilde resmedilmiştir (Resim 4-5). Yaratıcının karşısında ise uyuyan bir erkek figürünün sırtının içinden çıkar gibi tasvir edilen bir kadın figürü görülmektedir. Resimlerin arka planlarında yer yer yeşil yapraklar ve meyve ağaçları vardır. Bazı örneklerde ise Tanrı figürünün arkasında melek tasvirlerine rastlanmaktadır (Resim 5). Arka planda canlı bir doğa izlenimi yaratma çabasının, bulundukları yerin cennet olduğunu ifade etmek için olduğu söylenebilir. Erken dönem örnekleri figür ve ortam bazında ikonografiyi karşılasa da, geç dönemde verilen eserlere kıyasla çizgiselliğin daha ön planda tutulduğu eserler olarak ifade edilebilir (Resim 4-5). Geç dönem eserleri arasında ise çok başarılı örneklere rastlamak mümkündür. Bu anlamda Michelangelo'nun dini ikonografide Yaratılış serüvenini de resmettiği, Vatikan'da bulunan Sistine Şapeli’ndeki Havva'nın yaratılışına dair tasviri çok özel bir çalışmadır (Resim 6). 


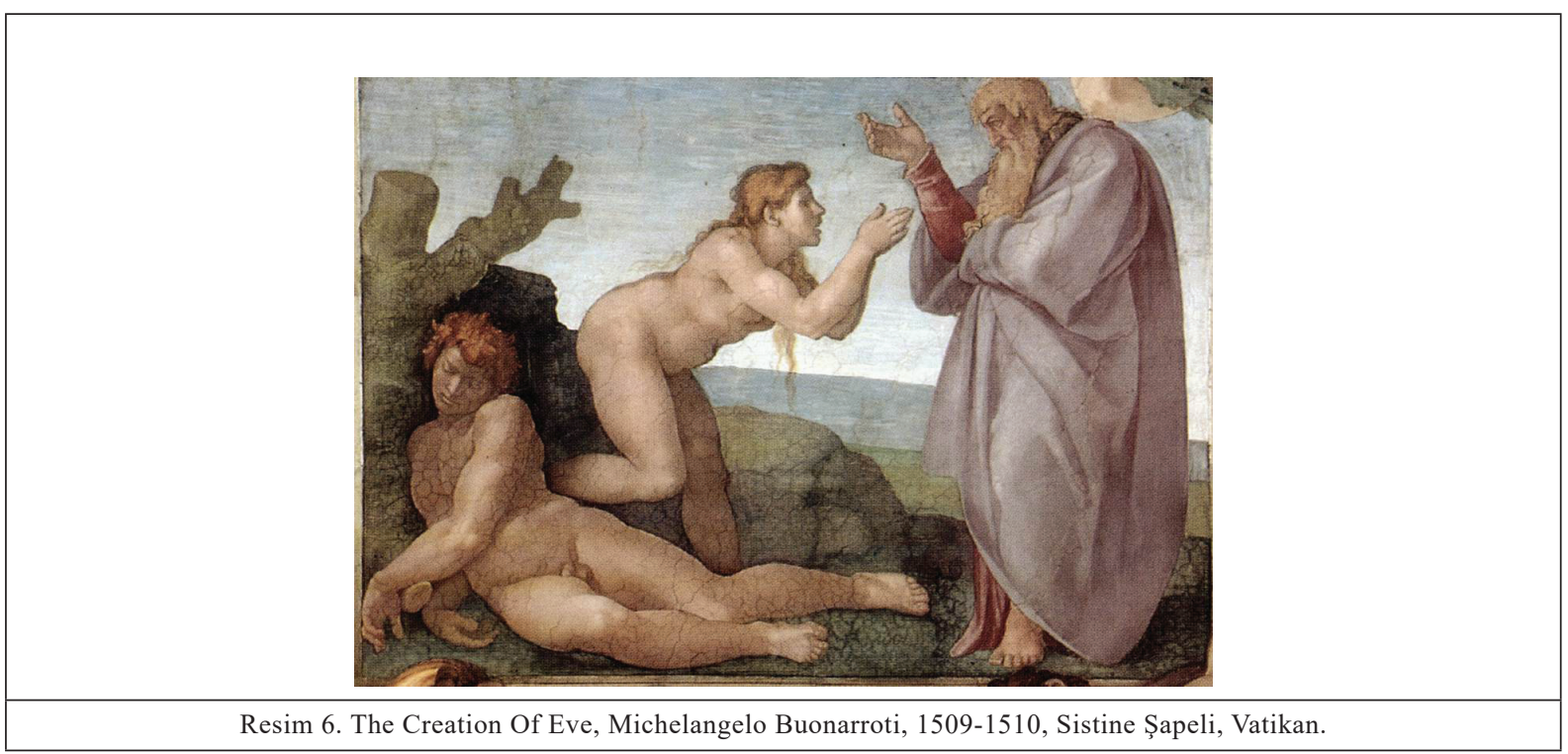

Michelangelo tarafından yapılmış olan The Creation Of Eve adlı duvar freskinde tıpkı erken dönem eserlerindeki gibi Tevrat ikonografisine sadık kalındığı anlaşılmaktadır (Resim 6). Bu eserde de diğer örneklerde olduğu gibi Havva, derin bir uykuda olan Adem' in kaburga kemiklerinden Tanrı tarafından yaratılırken görülmektedir. Diğer iki örnekte vücudunun yarısı ya da tamamı yaratılmış bir şekilde tasvir edilen Havva, burada elleri kavuşmuş bir şekilde Tanrı'ya tapınır vaziyette resmedilmiştir (Resim 6). İkonografisi ile birebir örtüşen bu eserlerin benzer örneklerini İslam minyatüründe görmek mümkün olmamıştır. İslam minyatüründe gerek -kesin bir yargıda bulunulmamakla birliktesözü edilen tasvir yasağının etkileri gerekse Kur'an-1 Kerim'de Havva'nın yaratılışına açıklama getirilmemiş olması sanatçıların bu olayı resmetme isteğini törpülemiştir denilebilir (Konak, 2013).

\section{Yasak Meyve ve Cennetten Kovulma}

Her iki kutsal kitapta da, Adem'in eşi Havva yaratıldıktan sonra Yaratıcı onları cennet bahçesinde, her çeşit imkanın içinde yalnızca bir ağaca yaklaşmamaları konusunda uyarmıştır. Ancak onlar Adem'e secde etmediği için kovulmuş olan Şeytanın oyununa gelmişlerdir ve yasağa uymayarak Yaratıcının gazabına uğramışlardır. Kur'an-ı Kerim'e göre cennetten kovulan Adem yakarışları ile Yaratıcıya kendini affettirmenin yollarını aramıştır. İlk Günah olarak da bilinen bu olay Adem ile Havva'nın yaratılış öyküsünde en çok işlenen konu haline gelmiştir. Yasak meyvenin yenmesi sahnelerinde genellikle -Tevrat'a göre Bilgi Ağacı olarak da bilinen- ağacın yanında betimlenen Adem ve Havva'nın yanı sıra ağaca dolanmış vaziyette yahut kertenkele şeklinde, kadın başlı, çocuk başlı vb. çeşitli biçimlerde ağacın arkasında gösterilen yılan figürü karşımıza çıkmaktadır. Kur'an- Kerim’in A'raf suresi 19.ayetinde, "Ey Adem! Sen ve eşin cennette yerleşip dilediğiniz yerden yiyin. Ancak şu ă̆aca yaklaşmayın, sonra zalimlerden olursunuz." ifadesiyle başlayarak devamında cennetten kovulma durumu anlatılmıştır. Aynı surenin 20.ayetinde, "Derken Şeytan birbirlerine kapalı ayıp yerlerini kendilerine göstermek için onlara vesvese verdi ve Rabbiniz size bu ă̆acı sirf melek olursunuz veya ebedi kalanlardan olursunuz diye yasakladı." ifadeleri yer almaktadir. Tevrat'ta ise, "Bahçede istediğin ăgacın meyvesini yiyebilirsin" diye buyurdu. "Ama iyiyle kötüyü bilme 
ă̆acından yeme. Çünkü ondan yediğin gün kesinlikle ölürsün. ”(Tekvin 2: 16-17) ifadeleriyle benzer bir anlatım görülmektedir. Devamında Havva tarafından bu yasağın çiğnenmiş olduğu anlatılmıştır. Onu bu hataya yönlendiren varlık ise Tevrat'ta, “...RAB Tanrı'nın yarattı̆̆l yabanıl hayvanların en kurnazı yılandı. Yılan kadına, "Tanrı gerçekten, 'Bahçedeki ağaçların hiçbirinin meyvesini yemeyin' dedi mi?" diye sordu."(Tekvin 3:1) ifadelerinden de anlaşılacağı üzere yılan ile bağdaştırılmıştır. Yılan, Tanrı'nın huzurundan kovulmuş Şeytanı temsil etmektedir. Her iki kitapta da yasaklanan ve bir meyve ağacı ile tasvir edilen durum, Adem ile Havva'nın birlikteliği olarak yorumlanabilir. Yaratıcı, bu birlikteliği onlara yasaklamış ancak onlar Şeytanın oyununa gelerek yasağı çiğnemişlerdir. Sanatçı Uccello tarafından yapılmış Creation of Eve and Original Sin adlı freskonun tamamı günümüze ulaşmamış olsa da, sol panelinde Tanrı Havva’yı yaratırken resmedilmiştir (Resim 7).

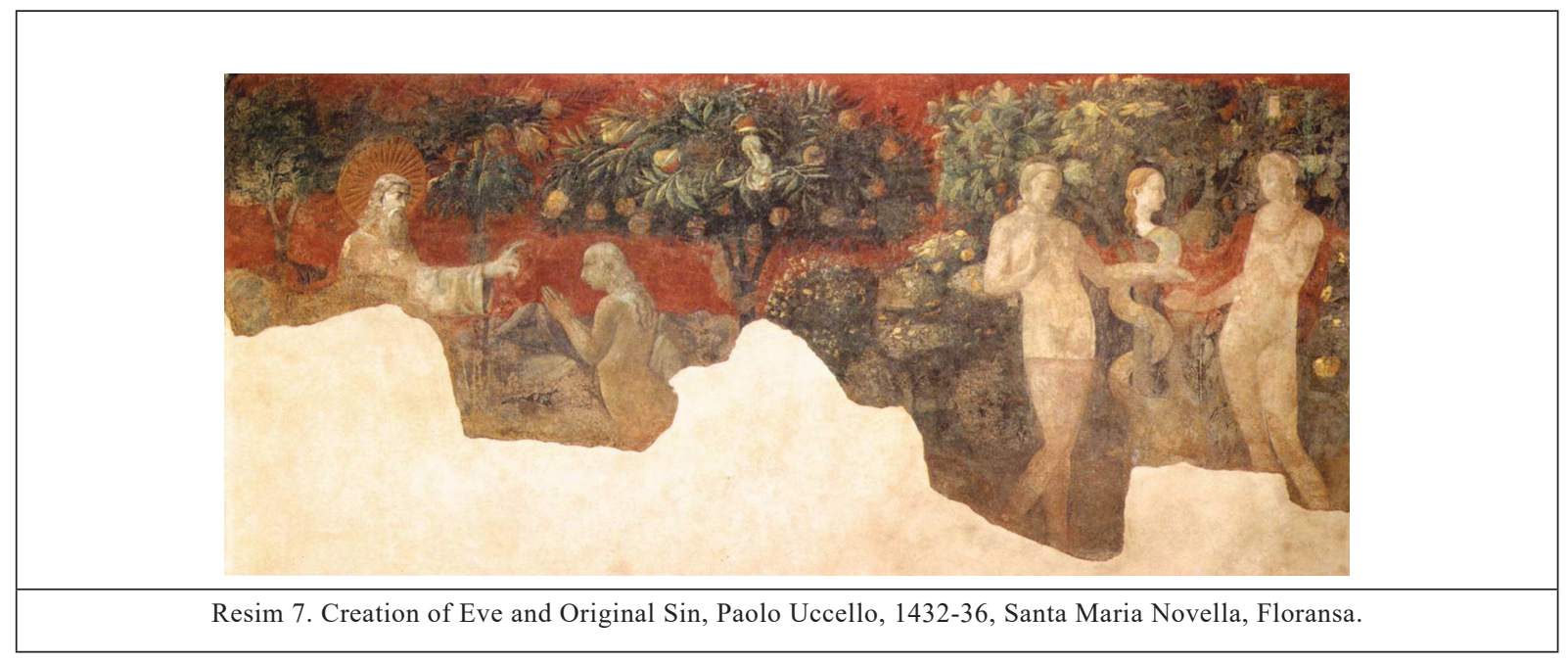

Başında halesi, sakallı ve yaşlı bir yüz ile insan olarak tasvir edilen Tanrı elini Havva’ya doğru uzatmıştır. Havva ise ellerini önünde birleştirmiş tapınır vaziyettedir. Resmin sağ panelinde ise bir ağacın iki yanında çıplak olarak Adem ve Havva resmedilmiştir (Resim 7). Gövdesi kadın başı ile tamamlanan ve ağaca dolanmış olarak resmedilen yılan figürünün yüzü Havva'ya dönüktür. Arka plandaki meyve ağaçları resmi hareketlendirmiş, bu şekilde Cennet betimlenmek istenmiştir. İsminden de anlaşılacağı üzere eserde, Tanrı Havva'yı yarattıktan sonra, Yasak Meyve'nin yenmesi sahnesi ile İlk Günah da gerçekleşmiştir denilebilir.

Tahmasb Falnamesi'nde yer alan bir minyatürde Adem bir ejderhanın Havva ise bir tavuskuşunun üzerinde cennetten kovulurken resmedilmiştir (Resim 8). Eski İran dinlerinde ve mitolojilerinde kutsal kabul edilen bu hayvanların minyatürde uygulanması eski inançların izlerinin İslam sanatında da görüldüğü şeklinde yorumlanabilir. Falname'de geçen bir minyatürde Adem ile Havva'nın cennetten kovulması farklı bir şekilde işlenmiştir. Minyatürde Adem, beş melek, şeytan, dört ayaklı yılan ve tavuskuşu figürleri bulunmakta ancak Havva figürü görülmemektedir (Resim 9). Adem başında alevden halesi ile yanındaki ağaca uzanmıştır, diğer yanında duran kırmızı elbiseli melek Adem'e bir şey söyler gibi resimlenmiştir. Şeytan arka planda tepenin ardında yanında iki melekle Adem'i izler şekildedir, minyatürün ön planında ise mekan çizgisine paralel olarak yerleştirilmiş kertenkeleye benzeyen dört ayaklı yılan figürü görülmektedir. Bu örneklerini gördügüumüz minyatür 
resimlere kıyasla farklı bir uygulamadır. Yılanın kuyruğunun minyatürün sağ alt kısmında verilen buğday başakları arasında olması sanatçının Yasak Meyve'yi buğday olarak yorumlaması şeklinde düşünülebilir. Tavuskuşu ise yılan figürünün sırtına binmiş şekilde resimlenmiştir.

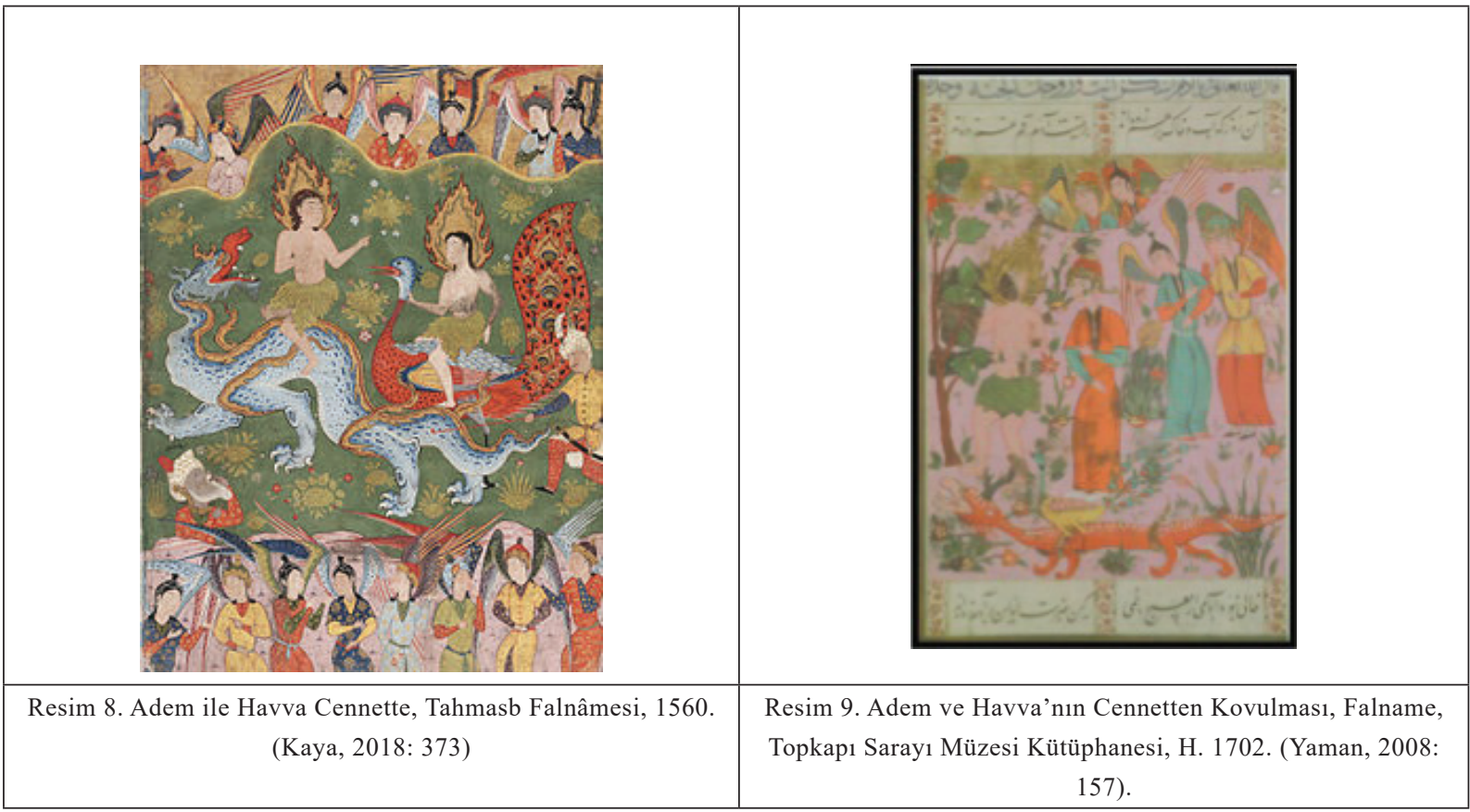

Yahudi kaynaklı bazı İslam metinlerinde yılan ve tavuskuşunun cennetin bekçileri olduğu, Şeytan tarafından kandırılıp tuzağa düşürülerek Adem ve Havva ile cennetten kovuldukları anlatılmaktadır (Çorakl1, 2012: 8). Buna bağlı olarak İslam minyatürlerinde yer verilen yılan ve tavuskuşunun da Adem ve Havva ile birlikte cennetten kovuluyorken resmedildiği düşünülebilir. Osmanlı Divan şairi Süleyman Fuzuli'nin eseri Hadikatü's Süeda'da yer alan ve çeşitli mekanlara ayrılan minyatürde cennetin içi ve dışı bir arada verilmiştir (Resim 10). Cennet bahçesinde melekler ile Adem ve Havva görülürken cennetin dışında ise Şeytan, tavuskuşu ve yılan figürü bulunmaktadır. Figürlerin yüzleri seçilmese de el ele tutuşan Adem ve Havva duruş pozisyonları ile ifadesel anlamda içinde bulundukları durumu yansıtmamaktadır. Burada Adem ve Havva cennetten kovulup dünyaya inerken Cebrail onlara yol göstermektedir (And, 2018: 170).

Nakkaş Hasan tarafından yapıldığı bilinen bir başka Falname minyatüründe ise figürlerin kalın kolları ile vücut hatları orantısızdır, yüzleri ise Orta Asya Türk tipini yansıtır şekilde yuvarlak ay yüzlü, kalem kaşlı ve badem gözlü olarak resmedilmiştir (Resim 11). Adem ve Havva'nın başları kutsallıklarını ifade eden alev şeklindeki halelerle çevrilidir. Adem'in halesinin Havva'nın başındaki haleden daha uzun olarak uygulanması ise sanatçının Adem'in peygamberliğini vurgulaması olarak düşünülebilir. Minyatürde Havva elinde buğday başakları tutmakta arkasında ise siyah bir yılan ve tavuskuşu görülmektedir. Havva'nın elindeki buğdaylar Yasak Meyve olarak yorumlanabilirken, Müslüman sanatçıların Şeytan'ı Tevrat'ta anlatıldığı şekliyle yılan olarak tasvir etmeleri ise oldukça dikkat çekicidir (Resim 11). Bunun yanında yılanı şirin bir görüntüyle vermeye çalışmış olmaları ise bireyselliğin yanı sıra Adem ve Havva'ya hoş görünen Şeytan algısını doğrular niteliktedir. İslam sanatında yılan, ejderha ve tavuskuşundan; Şeytan vb. dini bir imge olarak söz edilmezken 
minyatürlerde uygulamalarını görmemiz sanatçıların bireyselliği ile bağlantılıdır denilebilir.

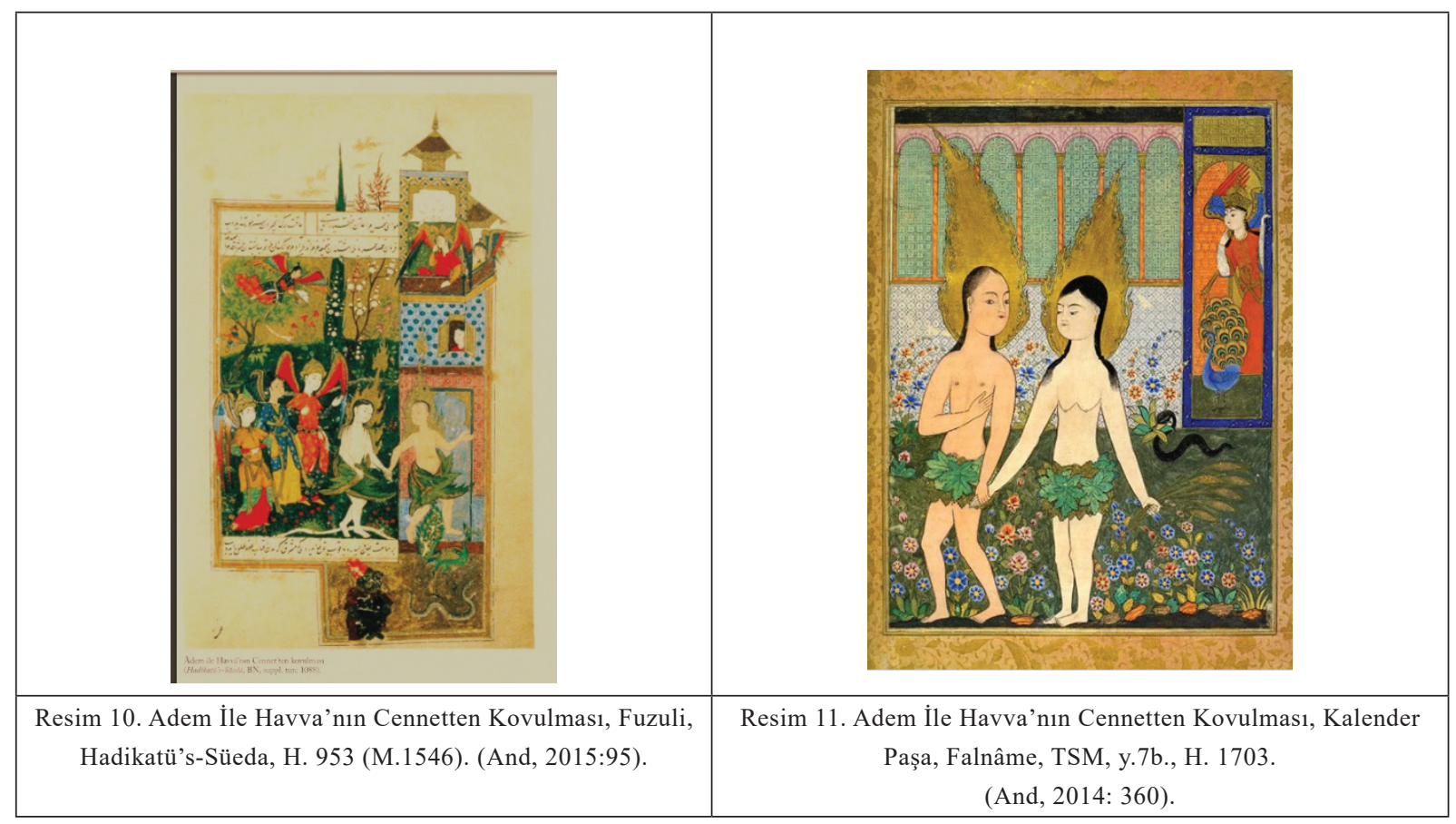

Burada ve diğer pek çok örnekte dikkat edilmesi gereken nokta her iki ana figürün de belden aşağılarının örtülü olmasıdır (Resim 8-9-10-11). Adem ve Havva'nın örtünme olayı Kur'an-1 Kerim'de A’raf suresi 22.ayette, “..Ăgacın meyvesini tattıklarında ayıp yerleri kendilerine göründü. Ve cennet yapraklarından üzerlerini örtmeye başladılar.” şeklinde ifade edilmektedir. Tevrat'ta ise “..Kadın ağacın güzel, meyvesinin yemek için uygun ve bilgelik kazanmak için çekici olduğunu gördü. Meyveyi koparıp yedi. Yanındaki kocasına verdi, o da yedi. İkisinin de gözleri açıldı. Çıplak olduklarını anladılar. Bu yüzden incir yaprakları dikip kendilerine önlük yaptılar.” (Tekvin 3: 6-7) ifadelerinden de anlaşıldığı üzere çıplaklıklarını farkettiklerinde incir yaprakları ile örtündükleri anlatılmıştır. Kur'an-1 Kerim'de açık bir şekilde ne bir meyve ağacından ne de örtünülen yaprağın türünden söz edilmemiştir. Eserlerde cennetten kovulan Adem ile Havva'nın belden alt kısımlarının yapraklarla örtülü olması sanatçıların ikonografilerine sadık kaldıklarını göstermektedir (Resim 10-11). Yasak Meyve sahnelerinde görülen bu uygulama, bunların yasak meyvenin yenmesinden sonraki sahneler olduğunu ayırt etmemizi sağlamaktadır. Yasak meyvenin yenmesinden önceki sahnelerde Batı resminde figürler çıplak olarak resmedilmiş, çıplaklıklarının farkında olmadıkları Kur'an ayetlerinde olduğu gibi Tevrat ikonografisinde de “..Adem de karısı da çıplaktılar, henüz utanç nedir bilmiyorlardl." (Tekvin 2:25) şeklinde ifade edilmiştir. İslam minyatürlerinde Cennetten Kovulma sahneleri, Panofsky'nin ifadesel anlamı ölçüsünde ise ikonografisine sadık kalınmayarak resmedilmiştir. Eserlerde, başlarındaki halelerle kutsallıkları ifade edilen Adem ve Havva cennetten kovulurken el ele görülmektedir. Kovulan ve yerilen insanlar olarak Adem ve Havva'nın, şenşakrak, halinden memnun, üzüntüden uzak yüz ifadeleri ile canlı ve hareketli bir doğa içinde tasvir edilmeleri, gerek figür gerek ortam bazında ifadesel anlam ölçüsünde ikonografi ile örtüşmemektedir. Panofsky'nin asıl anlam ve içerik ölçüsünde incelediğimizde ise, eserlerin ortaya koyuldukları dönemin izlerini yansıttıklarını, minyatür geleneğini sürdürdüklerini ve sanatçıların içlerinde 
bulunduğu dönemin şartlarını düşünerek İslam'da sözü edilen tasvir yasağına rağmen bireyselliklerini eserlerine yansıttıklarını da söylemek mümkündür.

El Biruni'ye ait El Asarü'l Bakiye ani'l Kuruni'l Haliye adlı eserin 1307-1308 y1llarında hazırlanan resimli nüshasında minyatürvari gelenekte resmedilen Adem ve Havva'nın Yasak Meyve sahnesi ise farklı bir örnek olarak karşımıza çıkmaktadır (Yaman 2008: 144) (Resim 12). Bu örnekte yılan figürüne yer verilmemiş, Adem ve Havva başları hale ile çevrili vaziyette, bir ellerinde meyve tutarken diğer elleri ile belden aşağılarını örter şekilde çıplak olarak resmedilmişlerdir. Karşılarında kendilerine elindeki meyveyi uzatır şekilde mavi giysisi, beyaz sakalları, başında beyaz sarı̆̆ı ve sarı̆̆ının arkasında hale ile bir erkek figürü görülmektedir. Bu figürün Havva’yı kandıran ve Yasak Meyve olayının gerçekleşmesini sağlayan Şeytan tasviri olduğu düşünülebilir. Eser minyatür geleneğine kıyasla yer yer gelişmişliği ve konuyu işleyişi açısından oluşturduğu farklılık ile dikkat çekmektedir. Fakat nihayetinde ikonografiyi tam anlamıyla yansıtmadığı da aşikardır.

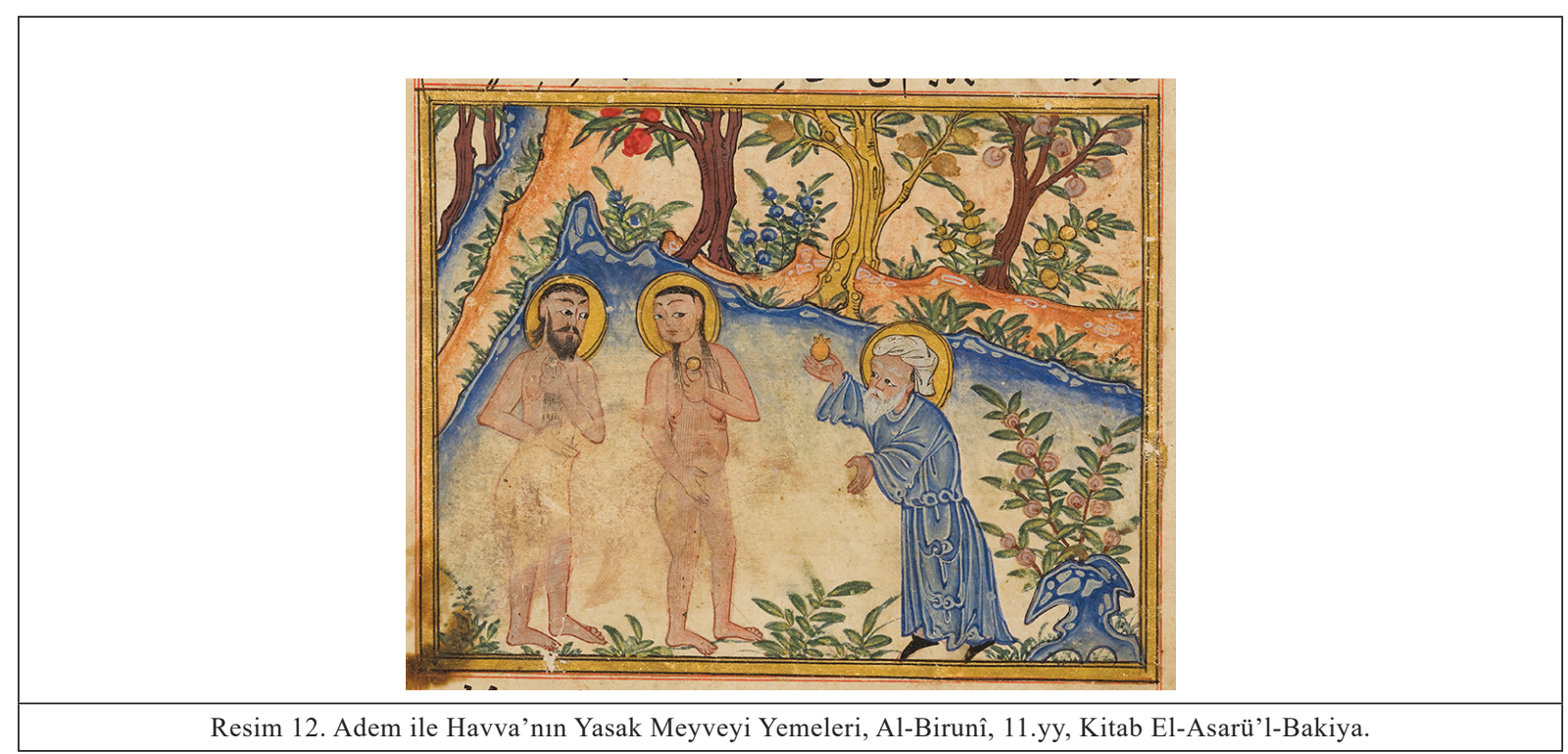

Minyatürlerden farklı olarak görülen freskler ise Batı tarzında oluşturulmuş örneklerdir. $\mathrm{Bu}$ örneklerde yasak meyvenin yenmesi bir ağaç etrafında Adem ve Havva ile ağaca dolanmış vaziyette görülen yılan ile anlatılırken; meyve ağacı, Havva'nın Adem'e meyveyi uzatır şekilde resmedilmesi ve yılanın başının daima Havva'ya dönük olması ise bu eserlerin Tevrat ikonografisine ne derece sadık kaldıklarını ortaya koymaktadır. Zira Tevrat'ta yılan, Havva yalnızken yanına gelerek onunla konuşmaktadır. Ona, “..Tanrı biliyor ki o ăgacın meyvesinden yerseniz gözleriniz açılacak, iyiyle kötüyü bilecek ve Tanrı gibi olacaksınız.” (Tekvin 3:5) demektedir. Bunun üzerine, “..Kadın ăgacın güzel, meyvesinin yemek için uygun ve bilgelik kazanmak için çekici olduğunu gördü. Meyveyi koparıp yedi. Yanındaki kocasına verdi, o da yedi. İkisinin de gözleri açıldı. Çıplak olduklarını anladılar. Bu yüzden incir yaprakları dikip kendilerine önlük yaptılar." (Tekvin 3: 6-7) ifadelerinden de anlaşılacağı üzere Havva meyveyi yiyerek, Adem'e de uzatmış ve bu hataya onu da sevk etmiştir. Eserler de bu şekilde Tevrat ikonografisi ile örtüşür nitelikte oluşturulmuştur.

Kutsal kitaplarda meyve ağacının türünden söz edilmemiştir. Ancak Batı resminde Avrupalı sanatçılar genellikle Yasak Meyve ağacını elma ağacı formunda resimlemişlerdir. Yasak Meyve, Yasak Elma 
adı ile anılma durumuna gelmiştir. Bazı İslam tasvirlerinde Yasak Meyve buğday başağı olarak resimlenirken, Tevrat kaynaklı Batı resimlerinde elma ile bağdaştırılmaktadır. Elma ağaçları dünya anlatılarında yeniden doğuşun ve üremenin sembolü olarak bilinmektedir (Bilgili, 2018: 214). Ancak bunun dışında "elma” kelimesinin Latince'de Malus yani Kötü- Günah anlamında olması da, elma ağacı tasvirinin İlk Günah ile ilişkilendirilmesi yorumunu güçlendirmektedir (Akyıldız, 2017: 10441045). Meyve ağacının türü bilinmezken eserlerde elma ağacı olarak görülmesi ikonografinin bu konuda birebir uygulanmayışını göstermektedir.

Konuyla ilgili olarak Batı sanatından incelenecek ilk resim Hollandalı ressam Hyronymus Bosch'un Tyriptych of Garden of Earthly Delights adlı tablosudur. (Resim 13). Eser özgün bir sanatçı olan ve kendi iç dünyasında farklı bir şekilde yaşayan sanatçının bireyselliğinin çok önemli bir örneğidir. Cennet'te Tanrının Havva'yı Adem'in kendisinden yarattıktan sonra, onları yasak meyvenin yenmemesi konusunda uyarırken resmettiği düşünülebilir. Burada figürlerin çıplak olmaları Yasak Meyve durumunun henüz gerçekleşmediğine işaret etmektedir. Resimde Adem'in arkasında resmedilen meyve ağacı ise bu durumun ifadesi için oldukça uygundur. İkonografiye sadık kalınmış ancak bireysellik bu eserin her alanında ön planda tutulmuştur.
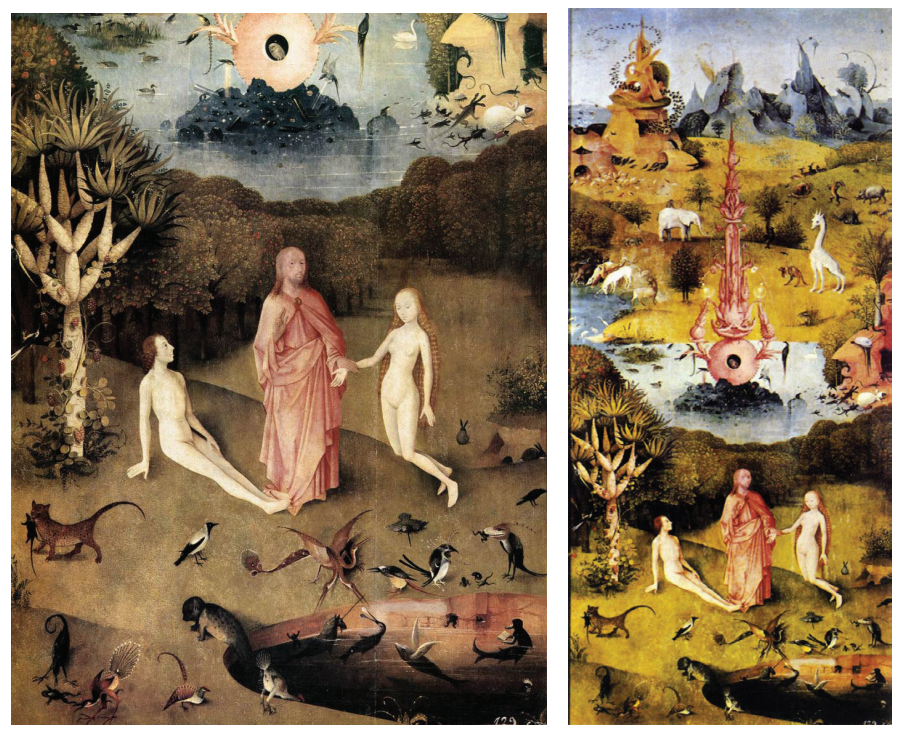

Resim 13. Tyriptych of Garden of Earthly Delights, Hieronymus Bosch, 1500, Prado Müzesi, Madrid.

Ressam Hugo Van-Der Goes tarafindan yapılan yasak meyvenin yenmesi sahnesinde yılan ağaçta değil, Adem ve Havva'nın yanında ayakta duran kuyruklu ve insan başlı bir yaratık şeklinde resmedilmiştir (Resim 14). Belden alt kısımları oldukça küçük ve mavi renkli bir çiçek ile örtülmüş vaziyette görülmektedir. Yasak meyvenin yenmesinden sonraki sahne olduğu anlaşılan bu eser eşsiz bir örnektir. Tüm bu eserler yasak meyvenin yenmesi sahnesini canlandırmaktadır. Çocuk başlı, kadın başlı veya ejder başlı olarak resmedilen yılanlar farklı uygulamalardır. Sanatçılar tarafından yılanların çocuk başlı resmedilmesi çocuğun masumiyeti ve ikna edebilirliğinin, kadın başlı olması ise Adem'i Havva'nın kandırdığının vurgulanmak istenmesi olarak düşünülebilir. Aynı zamanda sanatçının iç dünyasında kadınlara duyduğu öfkenin yansıması olabileceği şeklinde de 
yorumlanabilir. Jan Gossart'1n Adem ve Havva tasvirinde ise Rönesans'ın antikiteye dönüş fikrini özümsemiş olduğu ve figürde mükemmeliyetçilik anlayışını uyguladığı görülmektedir (Resim 15). Adem'in vücudu tıpkı Yunan heykellerini andırır şekilde adeleli ve kaslı olarak, Havva ise dolgun hatlarıyla, soluk ve ifadesiz bir yüzle resmedilmiştir. Belden alt kısımları oldukça ufak birer yaprakla sembolik olarak örtülmüştür. Ağaçta abartılı uygulamalardan uzak, gerçekçi şekilde resmedilen yılan, Havva'nın eline meyveyi bırakır şekilde uzanmıştır. Figürlerin kıvırcık saçları ve belirgin yüz ifadeleri sanatçının bireyselliği ile oldukça gerçekçi bir görünüm sunmaktadır. Arka planda yeşilin benzer tonları ile izleyicide soğuk bir his uyandıracak şekilde yaşayan bir doğa resmedilmiştir. $\mathrm{Bu}$ bireysel uygulamalar Batı tarzı resmin vazgeçilmezi haline gelmiştir. İkonografiye belirli ölçülerde sadık kalmış olmalarının yanında özgün uygulamalarının varlığı farklı bir izlenim de yaratmıştır.

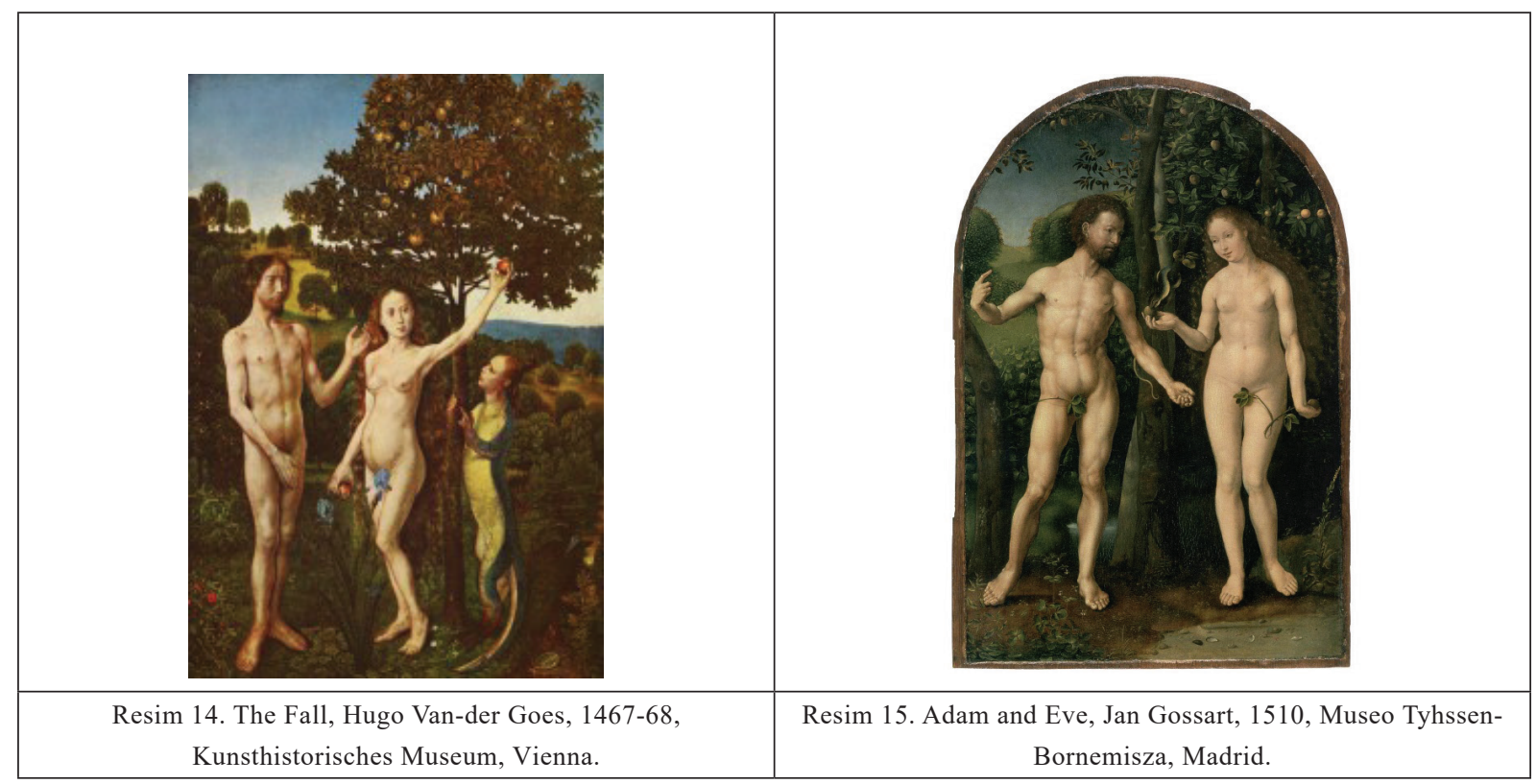

Dini konuları resmetme merakı yahut sorumluluğu taşıan sanatçılar, insan soyunun başlangıcını anlatan bu Yaratılış hikayesini eserlerine taşırken zaman içerisinde çağın getirdiği yeni sanat akımları ve uygulamaları ile bir dönüşüm yaşamışlardır. Işık ve gölge oyunları, canlı veya solgun renkler, figürlerin yüz ifadeleri ve vücut dillerindeki gelişmişlik, anatomik idealizm doğrultusunda vücut hatlarının belirginleşmesi, zaman zaman hatları daha belirgin ve adeleli figürlere yer verilmesi vb. uygulamaların sanat eserlerinin çeşitlenmesini ve yaşadıkları toplumlarda daha çok merak uyandırmasını sağladıkları düşünülebilir. Adem ve Havva sahnelerinin bu gelişim süreci içerisinde uygulanması çok sayıda özgün eserin ortaya koyulmasına sebep olmuştur. Haliyle gelişen ve değişen Batı sanatında yer edinen bu eserler, ikonografiyi Tevrat'tan alıp değişik şekillerde uygulayan sanatçıların elinden çıkmıştır. Hugo Van- der Goes ve Jan Gossart'ın yapmış oldukları resimler (Resim 14-15) gerek konu açısından gerekse olgusal anlamda aynı özellikleri taşıyor olsalar da hikayenin işlenişini bireyselliği ile harmanlamış sanatçıların ürünleri oldukları görülmektedir.

Örnekleri çoğaltmak mümkün olmakla birlikte, resimlerin benzerliklerinden ziyade, gelişimleri ve farklılıkları esas irdelenecekleri konu halini almaktadır. Ortamlar değişmekte, figürlerin yanı sıra çevresel unsurlar da azalmaktadır. Örneğin Albrecht Dürer tarafından yapılan Adam and Eve 
resminde ikonografiye konu olan ağaç artık merkezde değildir, canlı ve yeşil bir doğa yoktur ve arka plan karanlıktır (Resim 16). Ayrıca hem Adem hem de Havva figürleri ellerinde elma tutmakta ve birer daldan uzanan ufak yapraklar ise belden aşağılarını örtmektedir. Bu eser Batı sanatında artık ikonografiye olan sadakatin değişmesine önemli bir örnektir. Zira elma, yılan ve belden aşağılarının örtülü olması vb. simgesel uygulamalar dışında eser bize ikonografiyi anlatmaktan oldukça uzaktır. Küçük yaşta Albrecht Dürer'e hayranlığı ile onun dağ çiçeklerini ve böcekleri resmettiği gravürlerini kopya eden Tiziano ise kendi çağında şöhretin en üst noktasına ulaşmış bir sanatçı olarak Adem ve Havva betimini (Resim 17) ikonografiye sadık kalması, başarılı kompozisyonu, figürlerdeki ve ortamdaki gerçeklik, doğayı aynen yansıtan renkleri ile çağdaşlarına örnek teşkil edecek bir başarı ile uygulamıştır (Altuna, 2019: 58). Ressam yılanı bir çocuk gövdesiyle tasvir etmesinin dışında her anlamda ikonografiye sadık kalmıştır.

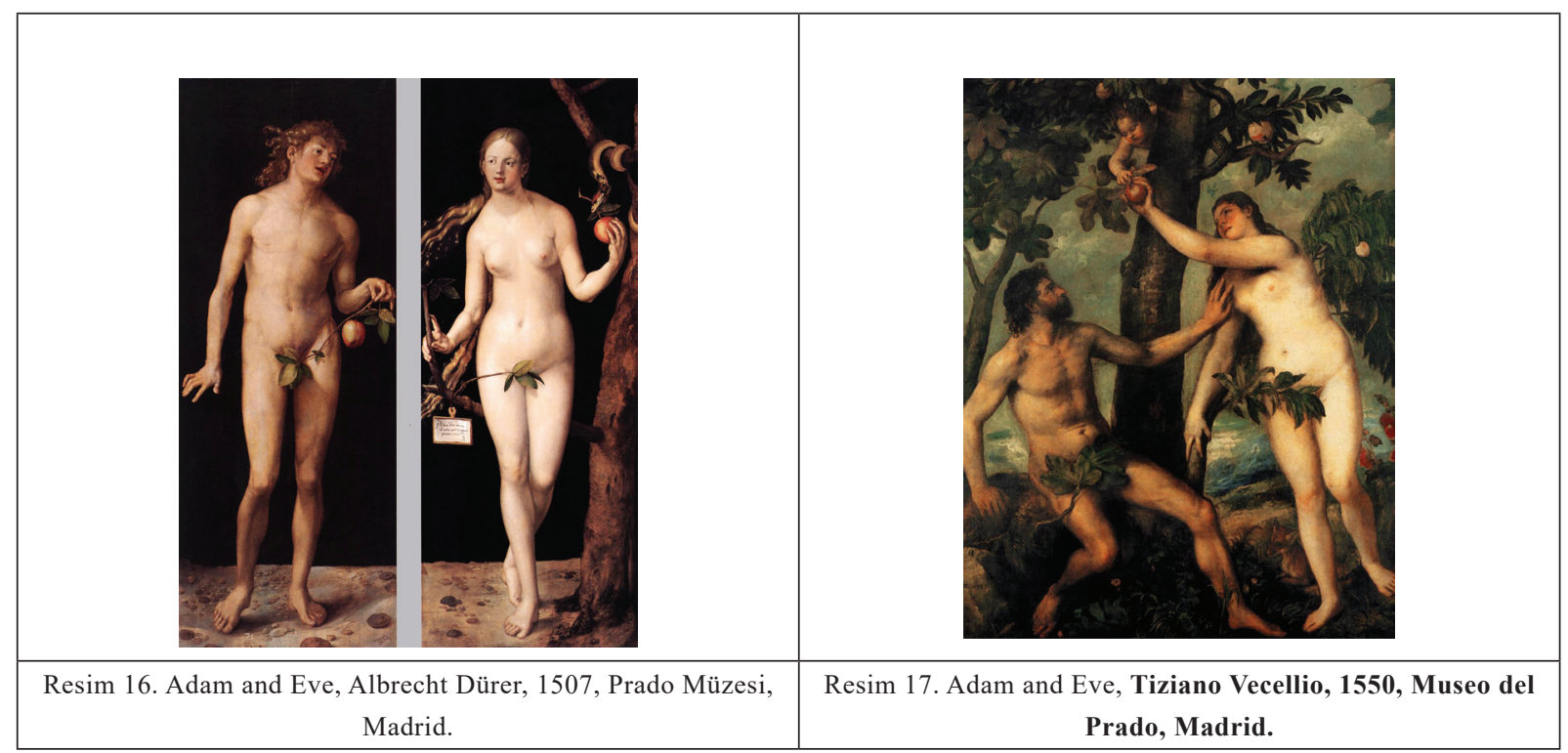

Michalengelo tarafindan resmedilen The Fall and Expulsion from Garden of Eden adlı eserde ise önce Yasak Meyve ardından ise Cennetten Kovulma sahnesi aynı kompozisyon içinde canlandırılmıştır (Resim 18). Ortadaki tek ağaç, resmi ikiye böler vaziyette verilmiştir. Sağ tarafta yasak meyvenin yenmesi sahnesinde yaşayan bir doğa, sol tarafta ise cennetten kovulmaları sahnesinde ölü bir doğa resmedilmiştir. Resmin sağ tarafında kadın başı bir yılan ile Havva'nın iletişim halinde oluşu ve hallerinden gayet mutlu görünmeleri dikkat çekicidir. Buna karşın resmin sol tarafinda Tanrı tarafından kovulurken görülen Adem ile Havva gerek duruş pozisyonları gerekse yüz ifadeleri ile durumun ciddiyetini yansıtır şekilde verilmişlerdir. Denilebilir ki eser ikonografiye sanatçının bireyselliği ölçüsünde sadık kalmış, sanatçı Panofsky’nin anlam teorisinde yer alan ifadesel anlamı gerek figür gerek ortam bazında başarılı şekilde yansıtmıştır. 


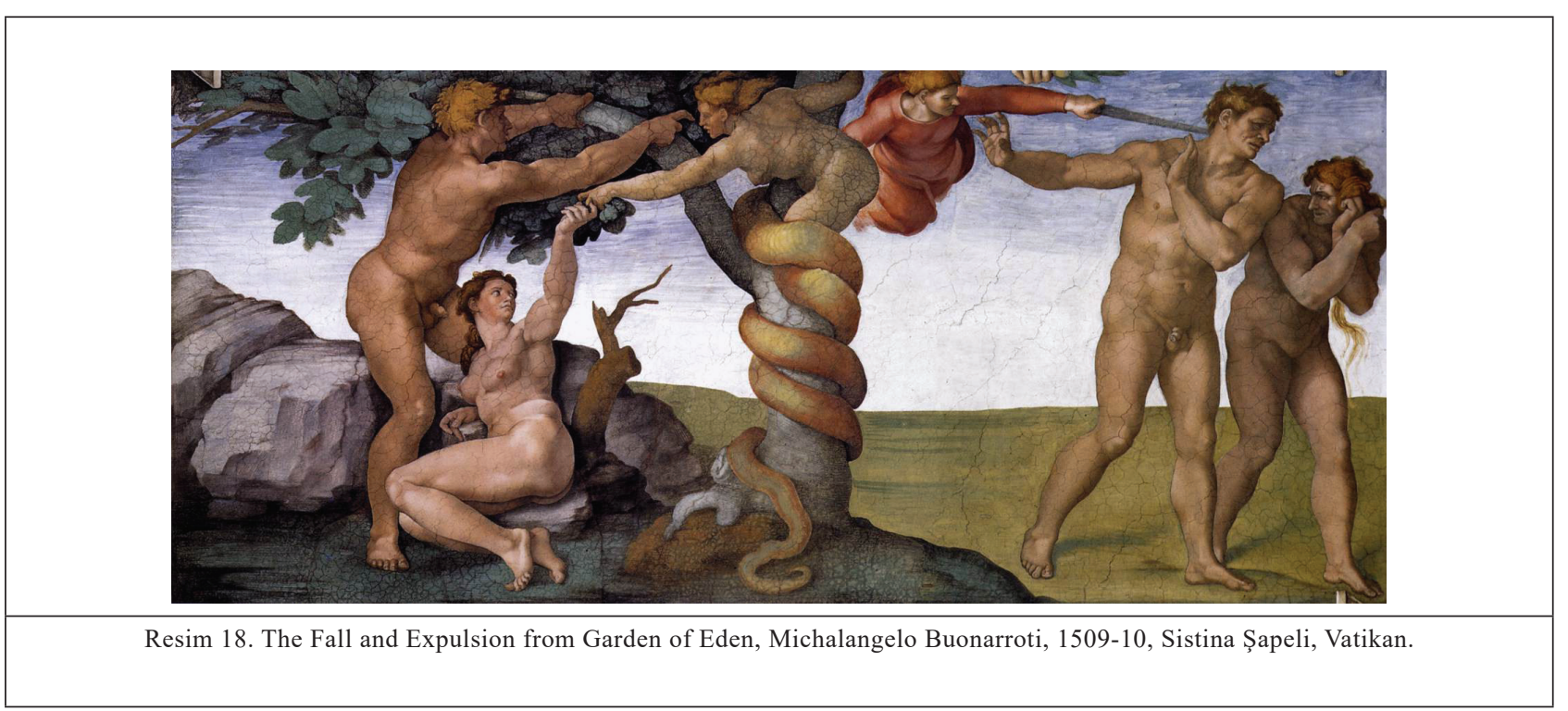

İlerleyen örneklerde ise artık iki boyutun tamamen terk edilmiş olduğu, Cennet bahçesinin çok gelişmiş şekilde resimlendiği, ağaçtaki yılan figürünün gerçekçi uygulamaları ve Havva’nın elmayı Adem'e uzatıyor oluşu net bir şekilde görülmektedir. Resimlerine sayısız figür katan ve normalde günlük hayatı resmetmeyi seven Jan Brueghel'in, çok canlı ve saf renk dizisiyle ortaya koyduğu The Garden of Eden with the Fall of Man adlı eseri gelişmiş tasvirlere spesifik bir örnektir (Resim 19).

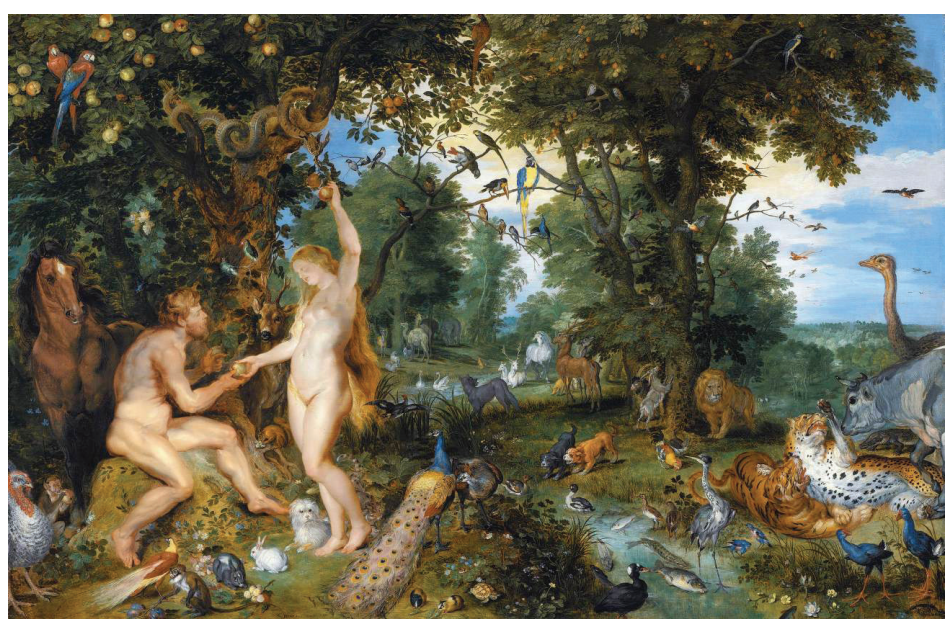

Resim 19. The Garden of Eden with the Fall of Man, Jan Bruegel the Elder-Peter Paul Rubens, 1615, Mauritshuis, The Hauge.

Her çeşit hayvan figürü, yeşil doğa, mavi gökyüzü, hatta akan nehirde yüzen balık detayları ile mükemmel perspektif bilgisini yansıtan sanatçının bu eseri döneminin önemli bir örneği olmuştur. Resimde Havva Adem'e meyveyi uzatmıştır ve yüzleri birbirlerine dönüktür. Ağacın dalına dolanmış gövdesiyle gördüğümüz yılan figürü ise gerçek hayattakinden farksızdır (Resim 19). Bu eserden farklı olarak bazı eserlerde yılanın kadın veya çocuk başlı olarak resmedildiği hususu dikkat çekmektedir. Sanatçıların eserlerine bireyselliğini yansıtma arzusu, ikonografiyi bu uygulamaları ile hiçe saymalarına ortam hazırlamıştır denilebilir.

Massaccio tarafından yapılan iki eserde ise, Adem ve Havva cennetten kovulurken görülmektedir 
(Resim 20). İki eser birbirlerinin birer kopyası olmakla beraber, birinde belden alt kısımları yapraklarla örtülü şekilde verilmiştir. Figürler çok üzüntülü bir şekilde, pişmanlıklarını ifade eden duruş ve yüz ifadeleri ile resmedilmişlerdir. Resimde Adem elleri ile yüzünü kapamışken, Havva bir eli göğsünde diğer eli belden alt kısmında resmedilmiştir. Burada sanatçının Havva'nın çıplaklığından duyduğu rahatsızlığı resimlemek istediği yorumu yapılabilir. Adem'in yüzünü elleri ile saklaması ise Yasak Meyve'nin yenmesinden, Tanrı'nın yasağını çiğnemiş olmasından duyduğu utancı ifade etmektedir. Figürlerin arka planında beyaz kemerli bir kapı görülmektedir, bu kapı cennet köşkünün kapısı olarak yorumlanabilir. Kapının üst kısmında gökyüzünde kırmızı elbisesi, kırmızı büyük kanatları ile resmedilen melek figürü İslam minyatüründe de örneklerini gördüğümüz, Yaratıcının emir ve yasaklarını peygamberlere ileten ve ayrıca meleklerin en büyüğü olarak anılan Cebrail ile bağdaştırılabilir. Meleğin kızgın bir ifade ile figürleri kovar şekilde resimlenmesinin yanı sıra sağ elinde siyah bir kılıç tutuyor olması dikkat çekicidir. Adeta cennet köşkünü korumakla görevli gibi gösterilmek istenmiştir. Massaccio bu eseri ile arka planda yaşayan bir doğaya yer vermemiş olması, figürlerin duruşlarında ve yüz ifadelerinde pişmanlıklarının net olarak hissedilmesi ile kovulan ve yerilen insanlar olarak Adem ve Havva'yı ifadesel anlamda figür ve ortam bazında başarıyla resmetmiştir. Sanatçının ikonografiyi uygulama şekli kendine has üslubu ve vermek istediği ince mesajlar ile oldukça başarılıdır.

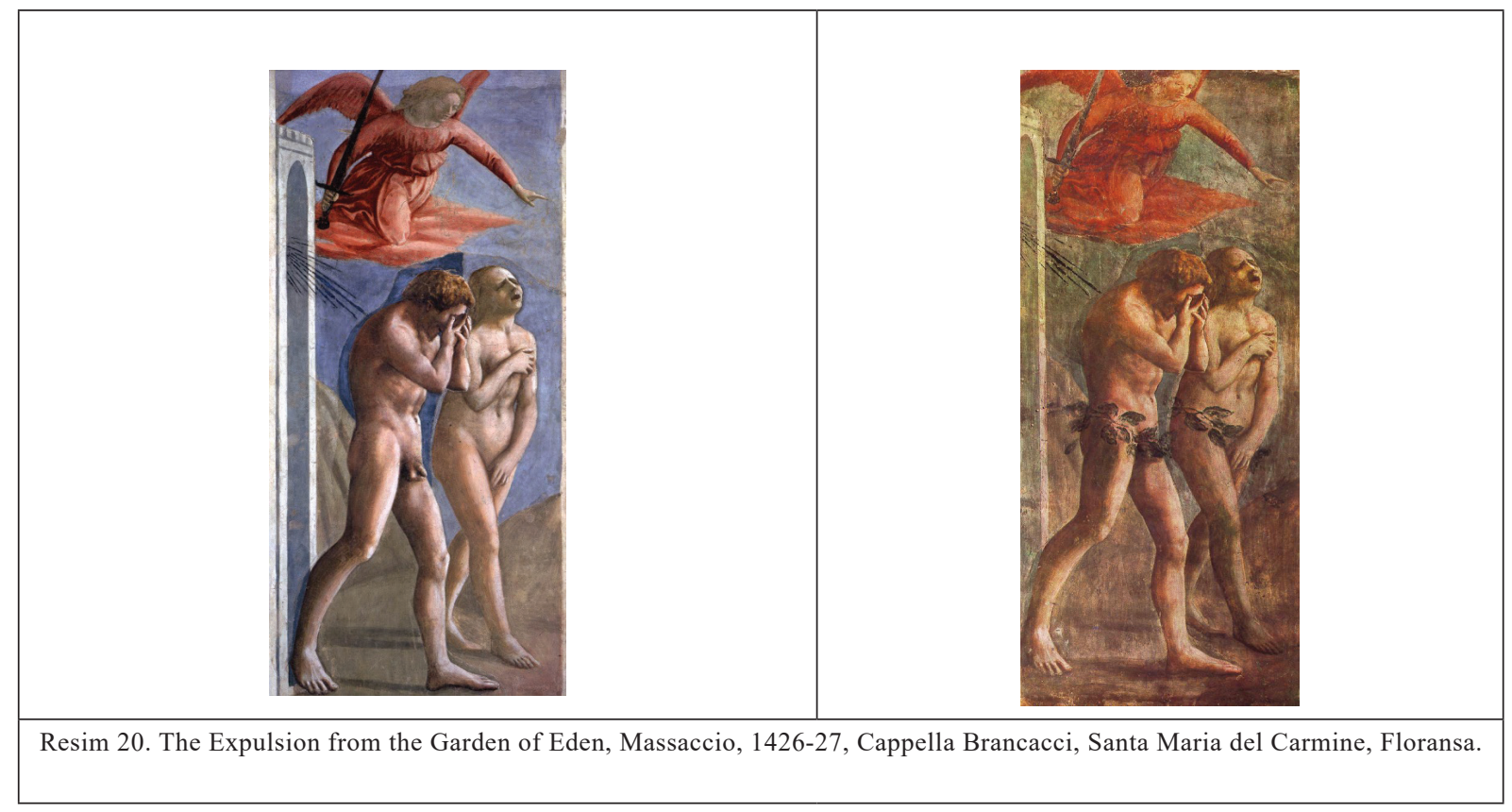

Yasak Meyve sahnesinin tasvir edildiği bir İran minyatüründe figürler mutlu, yarı çıplak vücutları ise kumaşlarla örtülü vaziyette resmedilmiştir (Resim 21). Kutsallıklarının ifadesi olarak başları halelerle çevrilmiştir ancak bu minyatürde gördüğümüz hale uygulaması diğer örneklerden farklıdır. Bu tarz haleler daha çok Hristiyan resimlerinde karşımıza çıkmaktadır. Türk-İslam resimlerinde ise kutsallık işareti olarak görülen hale uygulaması peygamber tasvirlerinde alev biçiminde yorumlanmaktadır. 


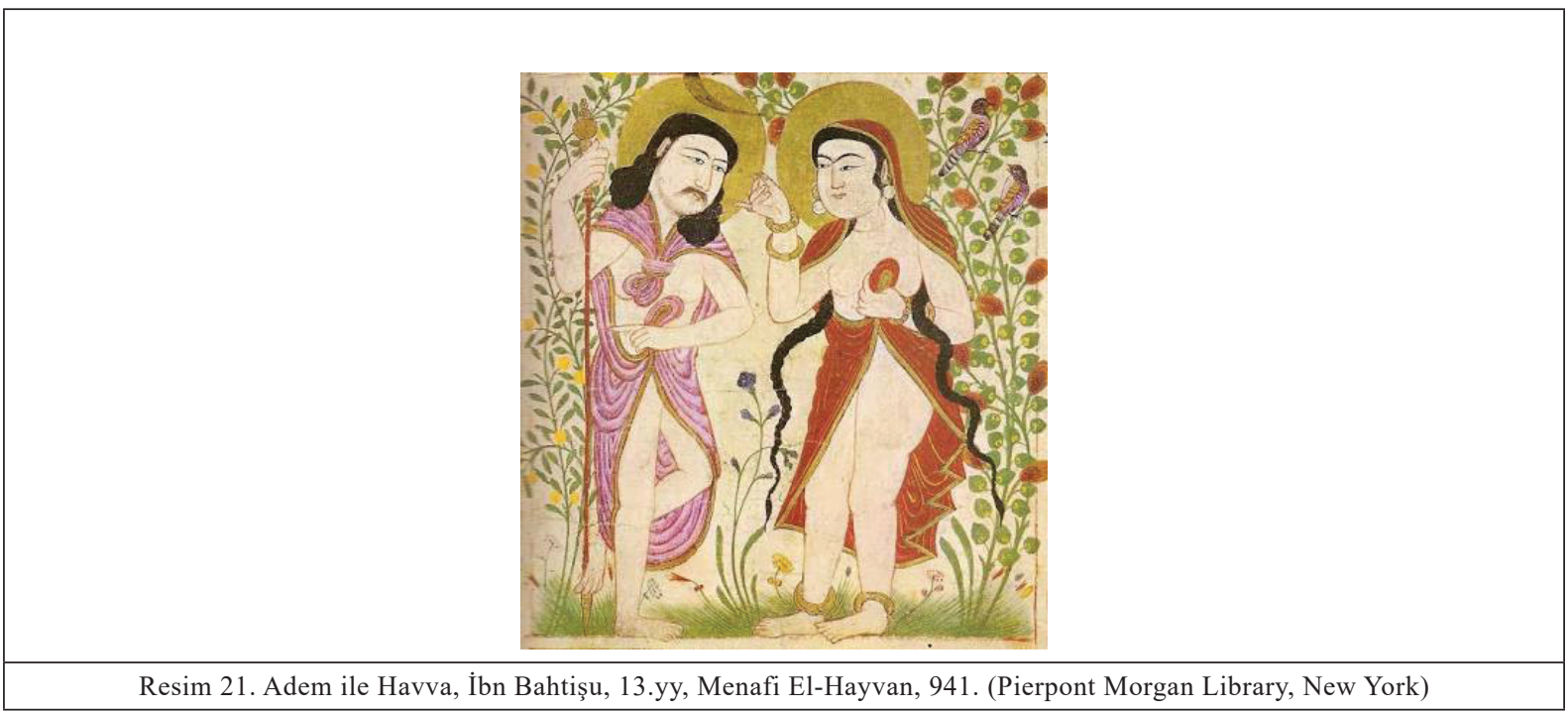

Figürler Orta Asya Türk tipi olarak bilinen ve Selçuklu seramiklerindeki figür tiplerine benzer şekilde yuvarlak ay yüzlü, çekik gözlü ve gür saçlı olarak resmedilmişlerdir. Adem sağ eliyle bir asa sol eliyle ise üzerindeki kumaşı tutmaktaktadır. Adem'in yüzündeki düşünceli ve üzgün ifade pişmanlığını gösteren bir uygulama olarak yorumlanabilir. Havva figürünün yüzünde görülen hafif tebessüm ise halinden memnun olduğu izlenimini yaratmaktadır ve bu anlamda minyatür ifadesel olarak figür bazında ikonografi ile örtüşmemektedir (Resim 21). İkonografiyi birebir yansıtmasa da Yaratıcı tarafından Adem'in yakarışları kabul gördükten sonra onlar için giysiler yapıldığı ifadesi kutsal kitaplardaki bir başka bilgidir. Bu durum A’raf suresi 26. ayette, “..Ey Ademoğulları! Size avret yerlerinizi örtecek giysi ve süslenecek elbise verdik." şeklinde geçerken Tevrat’ta ise, "RAB Tanrı Adem'le karısı için deriden giysiler yaptı, onları giydirdi." (Tekvin 3:21) ifadesiyle anlatılmıştır. Minyatürde kumaş ile örtünmeleri İran minyatüründe bu açıklamayı destekler nitelikte örnekler verilmiş olduğunu göstermektedir(Resim 21). Figürlerdeki sadelik, duruş pozisyonlarındaki anatomik bozukluklar, iki boyutluluk, gerek yüz ifadeleri gerekse vücut proporsiyonları ile birbirlerine benzer olmaları ve figürlerin iki taraftan şematik bitkilerle çevrelenmesi; sanatçıların resim geleneğinde İslam tasvir üslubuna uygun olarak hareket ettiği şeklinde yorumlanabilir. Eserlerin figür bazında dönemin Selçuklu devri seramiklerinde de görülen bir üsluba uygun aktarımı ile Batı tasvir sanatından oldukça farklı olduğu görülür.

Konuyla ilgili 18. yüzyıla ait The Expulsion from Paradise adlı bir diğer resimde Adem ve Havva yaptıkları yanlışın üzüntüsü içerisinde tasvir edilmişlerdir (Resim 22). Adem ellerini önünde birleştirmiş, etrafı meleklerle çevrili olarak bulutların arasından yaşlı bir erkek tasviri ile gösterilmiş Tanrı figürüne yakarış içerisinde görülmektedir. Havva ise ağlıyormuş izlenimi verilerek resmedilmiştir. İkonografide yasak meyveyi yedikten sonra pişmanlık duydukları bilgisi verilmektedir. Ancak affedilmeyi diledikleri Tevrat'ta yer almamakta, Kur'an1-1 Kerim'de ise, A'raf suresi 23.ayette "Rabbimiz! Biz kendimize zulüm ettik. Eğer bizi bağışlamaz ve bize acımazsan mutlaka ziyan edenlerden oluruz.” şeklinde geçmektedir. Resim, Tevrat ikonografisinde yer verilmeyen Adem ile Havva’nın Tanrı'ya yakarış hikayesini Batı sanatında yansıtan özgün ve başarılı örneklerdendir. 


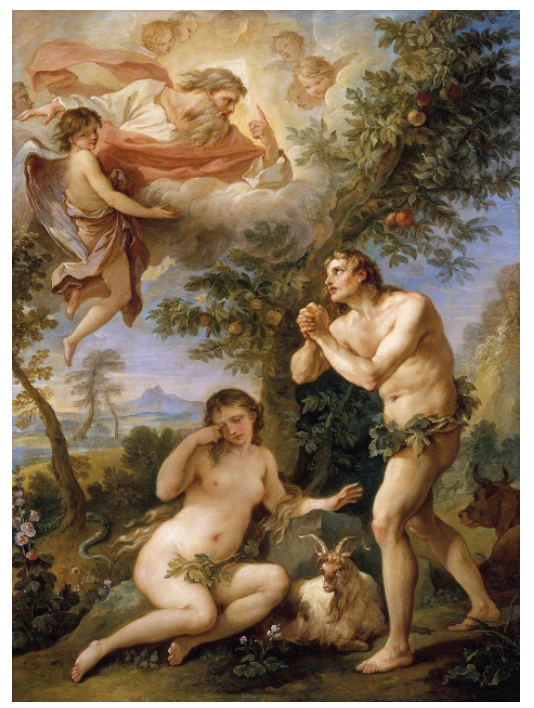

Resim 22. The Expulsion from Paradise, Charles-Joseph Natoire, 1740, Metropolitan Museum of Art, New York.

Nihayetinde, Adem'in yakarışlarının netice bulduğu ve affedildikten sonra soyun devamının geldiği bilinmektedir. Batı resminden farklı olarak İslam resminde Adem'in soyunun devam ettiğini ifade eden minyatürler bulunmaktadır (Resim 23-24). Seyyid Lokman Aşuri tarafından oluşturulan ve “Tarihlerin Özü” anlamına gelen Zübdetü’t Tevarih ’te Adem ve Havva bölümündeki minyatürlerde, soylarının kendilerinden doğan ikiz kardeşlerin birbirleri ile birlikteliklerinden devam edilişi anlatılmak istenmiştir (Renda, 1991). Tam ortada yer alan Hayat Ağacı ve Hayat Irmağı'nın iki yanına yerleştirilen Adem ve Havva etraflarında soylarını devam ettiren çocukları ve gökyüzüne dizilmiş meleklerle görülmektedir (Mahir, 2005: 156). İslam ikonografisine sadık kalınarak ortaya koyulan bu minyatürler, zarif çizimlerinin yanı sıra iki boyutlu figürleri, figürlerin benzerlikleri, perspektif algısının olmayışı ve canlı renkleri ile figür ve ortam bazında geç dönem Batı sanatı uygulamalarının çok gerisindedir. Ancak asıl anlam ve içerik açısından incelediğimizde ortaya koyulduğu dönemin ve ortamın şartlarını başarılı şekilde yansıtan minyatürler çağdaşları arasında özel ve önemli bir yer tutmaktadır.

\begin{tabular}{|c|c|}
\hline & \\
\hline Resim 23. Adem İle Havva ve On Üç İkizi, Zübdetü’t-Tevarih, & Resim 24. Adem İle Havva ve Sekiz İkizi, Zübdetü’t- \\
DCBL:1583, Tím:1973, y.18b, 1973. (And, 2015:98). & Tevarih, DCBL:1583, TíEM: 1973, y.53a. (And, 2015:98). \\
\hline
\end{tabular}




\section{Sonuç}

Tasvir sanatında karşılaştırmalı ikonografinin temeli, aynı konuda farklı sanatçıların ortaya koymuş olduğu eserler üzerinden yapılan incelemede, benzerlik ve farklılıkları ortaya koymak ve kaynak bilgisinin eserdeki yansımalarını irdelemektir. Bu mukayesede Alman Sanat Tarihçi Erwin Panofsky’nin eserleri yorumlamak için ortaya koyduğu Anlam Teorisi çok önemli bir yer tutmaktadır. Yol gösterici nitelikte olan bu teoriye göre çalışmada yer verilen eserler yorumlanmıştır.

Tasvirin yasak olarak iddia edildiği İslam coğrafyasına karşılık, Batı dünyasında Yahudi ve Hristiyanlar, sanatı dinin emrine vermiş ve bu şekilde kutsal kitaplarını daha kolay öğrenme firsatı edinmişlerdir. $\mathrm{Bu}$ anlamda karşılaştırmalı ikonografi noktasında benzerlikler görülse de Batılı sanatçıların eserlerindeki gelişmişlik ve konuyu ifade edişlerindeki vurgu dikkat çekicidir. Eserler, sanatçıların bireyselliğini ön plana taşımaktadır. Bunun yanında dini konuları başarılı bir şekilde uygulamışlardır. Özellikle Hristiyanların, kutsal kitap kabul ettikleri Tevrat ve İncil'i kaynak edinmeleri, sanatçıların yaptıkları resimler için esas olmuştur. Buna karşılık İslam coğrafyasında süregelen tasvir yasağı dolayısıyla, kutsal kitap Kur'an-1 Kerim'in kaynaklığında dini konuların resmedilmesi meşru kılınmamıştır. Ancak belli dönemlerde minyatür resim geleneği ile İslam inancı çerçevesinde resmedilmiş eserler olduğu da bilinmektedir. Çalışma içerisinde yer verilen minyatür resimler iki boyutlu çizimin ve tekdüzeliğin çok belirgin şekillerde yansıtıldığı örnekler olmuştur. Panofsky ölçeğinde değerlendirdiğimizde minyatürlerin hem ifadesel anlamda hem de ikonografik anlamda yetersizlikleri ön plandadır. Sanatçılar minyatürlerde figürlerin yüz ifadeleri ve duruş pozisyonlarında anlatmak istedikleri durumu doğru şekilde canlandıramamış,çizgiselliği daima ön planda tutmuş ve ortam bazında gereken hissi verememişlerdir. Ancak çizim sanatında üçüncü boyutun ve perspektifin hakim olduğu Batı resminde, dini tasvirlerde kısıtlamaların da olmayışı sanatçıların bireyselliğini olumlu ölçüde etkilemiştir. Ortaya koyulan eserler ikonografilerine büyük ölçüde sadık kalınarak oluşturulmuştur. Panofsky’nin teorisine uygun olarak ifadesel anlamı hem figür hem ortam bazında çok başarılı şekilde yansıtan eserler verilmiştir.

Bu çalışmada iki büyük kutsal kitapta önemli yer edinen Adem ile Havva olaylarının tasvirler üzerinden karşılaştırması yapılmıştır. Sonuç itibariyle bu karşılaştırma bizlere Batı tarzı resim ile İslam coğrafyasında yer alan minyatür resmini ve tasvirlerdeki sınırlamaların etkilerini de göstermiştir. Bunun yanı sıra eserlerin kutsal kitaplardaki bilgilere uygun olarak resmedilip resmedilmediğini ayırt etme imkanı sunmuştur.

\section{Kaynakça}

AKYILDIZ, E. (2017). Söylencelerde ve Masallarda Elma Sembolü, Atatürk Üniversitesi Sosyal Bilimler Enstitüsü Dergisi, 3(21), 1043-1060.

ALTUNA, S. (2019). Ünlü Ressamlar Hayatları ve Eserleri İstanbul: Hayalperest Yayınevi.

AND, M. (1998). Minyatürlerle Osmanlı İslam Mitologyası, İstanbul: Yapı Kredi Yayınları.

AND, M. (2018). Osmanlı Tasvir Sanatları 1: Minyatür, İstanbul: Yapı Kredi Yayınları.

BAYRAK KAYA, E. (2020). Adem ile Havva’nın Yaratılış ve Cennetten Çıkarılış Öyküsünün Minyatür Sanatına 
Yansımaları, Atatürk Üniversitesi Güzel Sanatlar Enstitüsü Dergisi, (35), 204-224.

BİLGiLİ, N. (2018). Türk Mitolojisi Türklerde Yaratılışve Evren Tasarımı, Ankara: Kripto Kitaplar.

CÖMERT, B. (2001). Mitoloji ve İkonografi, Ankara: De Ki Basım Yayım.

ÇORAKLI, B. (2012). Çini ve Seramiklerde Tavuskuşu Figürü, MSGSÜ Sosyal Bilimler Dergisi, (6).

DAĞLIOĞLU, A.-İNCE, M. (2018). İkonografi ve İkonoloji Eleştiri Yöntemine Göre Salvador Dali’nin “Çarmıhtaki Aziz Juan İsa’sı” Adlı Eserinin Analizi, Ulakbilge Dergisi, 6(26), 945-965.

İNAL, G. (1995). Türk Minyatür Sanatı (Başlangıcından Osmanlılara Kadar), Ankara: AKM Yayınları.

KAYA, H. Ö. (2018). Farklı Kültürlerden Osmanlı ve Ermeni Minyatür Sanatındaki Dini İçerikli Minyatürlerin Karşılaştırılması, Uluslararası Sosyal Araştırmalar Dergisi, 11(55), 370-399.

KONAK, R. (2013). İslam'da Tasvir Yasağı Sorunu ve Minyatür Sanatı, International Jorunal of Social Science, 6(1), 967-988.

MAHIR, B. (2005). Osmanlı Minyatür Sanatı, İstanbul: Kabalcı Yayınevi.

MINOR, V.H. (2013). Sanat Tarihinin Tarihi, (C. Soydemir, Çev.), İstanbul: Koç Üniversitesi Yayınları.

PANOFSKY, E. (1955). Meaning in the Visual Arts, New York: Doubleday.

PANOFSKY, E. (1995). İkonografi ve İkonoloji: Rönesans Sanatının Incelenmesine Giriş. (E. Akyürek, Çev.), İstanbul: Afa Yayınları.

RENDA, G. (1991). Chester Beatty Kitaplı̆̆ı'ndakiZübdetü’t Tevarih ve Minyatürleri, Prof. Dr. Bekir Kütükoğlu'na Armağan, İstanbul, 485-506.

TÜKEL, U.-YÜZGÜLLER, S. (2019). Sözden İmgeye Batı Sanatında İkonografi, İstanbul: Hayalperest Yayınevi.

YAMAN, B. (2008). Türk Minyatür Sanatında Cennet: Belleten, LXXII, 263, 144-156.

https://www.wga.hu/index1.html (24.04.2020)

https://digitalcollections.nypl.org/items/510d47da-e9af-a3d9-e040-e00a18064a99\#/?zoom=true (24.04.2020)

https://i.pinimg.com/originals/8f/34/18/8f3418f06c36fc1716094465c203f94f.jpg (24.04.2020)

http://libraryblogs.is.ed.ac.uk/diu/2016/05/12/al-biruni-live-on-luna/ (25.04.2020)

https://www.biblioiranica.info/adam-eve-in-zoroastrian-and-manichaean-literature/ (25.04.2020)

https://en.wikipedia.org/wiki/Falnama (09.05.2020) 